RODRIGO DA SILVA NUNES BARRETO

\title{
OCORRÊNCIA E MECANISMOS DO MICROQUIMERISMO FETAL EM GESTAÇÕES BOVINAS
}


Dissertação apresentada ao Programa de Pós-Graduação em Anatomia dos Animais Domésticos e Silvestres da Faculdade de Medicina Veterinária e Zootecnia da Universidade de São Paulo para obtenção do título de Mestre em Ciências

Departamento:

Cirurgia

Área de Concentração:

Anatomia dos Animais Domésticos e

Silvestres

Orientador:

Prof. Dr. Flávio Vieira Meirelles

São Paulo 
Autorizo a reprodução parcial ou total desta obra, para fins acadêmicos, desde que citada a fonte.

DADOS INTERNACIONAIS DE CATALOGAÇÃO-NA-PUBLICAÇÃO

(Biblioteca Virginie Buff D’Ápice da Faculdade de Medicina Veterinária e Zootecnia da Universidade de São Paulo)

Barreto, Rodrigo da Silva Nunes

Ocorrência e mecanismos do microquimerismo fetal em gestações bovinas / Rodrigo da Silva Nunes Barreto. -- 2011.

$68 \mathrm{f}$. : il.

Dissertação (Mestrado) - Universidade de São Paulo. Faculdade de Medicina Veterinária e Zootecnia. Departamento de Cirurgia, São Paulo, 2011.

Programa de Pós-Graduação: Anatomia dos Animais Domésticos e Silvestres.

Área de concentração: Anatomia dos Animais Domésticos e Silvestres.

Orientador: Prof. Dr. Flávio Vieira Meirelles.

1. Microquimerismo fetal. 2. Invasão trofoblástica. 3. Placentação bovina. 4. Células trofoblásticas gigantes. 5. TSPY. I. Título. 


\section{ERRATA}

BARRETO, R. S. N. Ocorrência e mecanismos do microquimerismo fetal em gestações bovinas. 2011. $68 \mathrm{f}$. Dissertação (Mestrado em Ciências) - Faculdade de Medicina Veterinária e Zootecnia, Universidade de São Paulo, São Paulo, 2011.
Página
Parágrafo
$2^{\circ}$
Onde se lê

Folha de Avaliação
Título:
Leia-se

Título: Ocorrência e mecanismos do microquimerismo fetal em gestações bovinas 


\section{FACULDADE DE MEDICINA VETERINARIA E ZOOTECNIA}

\section{CERTIFICADO}

Certificamos que o Projeto intitulado "Modelo de estudo de imunomodulação em bovinos: Expressão do MHC classe $1 \mathrm{~b}$ em células trofoblásticas e mesênquimais da placenta de conceptos clonados e naturais", protocolado sob o $\mathrm{n}^{\circ} 1678 / 2009$, utilizando 12 (doze) bovinos, sob a responsabilidade do Prof. Dr. Flávio Vieira Meirelles (UNESP/Dracena), tendo como pós-graduando envolvido o sr. Rodrigo da Silva Nunes Barreto, desta FMVZ, está de acordo com os princípios éticos de experimentação animal da Comissão de Bioética da Faculdade de Medicina Veterinária e Zootecnia da Universidade de São Paulo e foi aprovado em reunião de $20 / 05 / 09$.

We certify that the Research "Model of immunomodulation study in bovines: expression of MHC class $1 \mathrm{~b}$ in trophoblastic and mesenchymal cells in cloned conceptuses and natural placenta", utilizing 12 (twelve) bovine, protocol number $1678 / 2009$, under the Prof. Dr. Flávio Vieira Meirelles, agree with Ethical Principles in Animal Research adopted by Bioethic Commission of the School of Veterinary Medicine and Animal Science of University of São Paulo and was approved in the meeting of day $05 / 20 / 09$.

São Paulo, 21 de maio de 2009

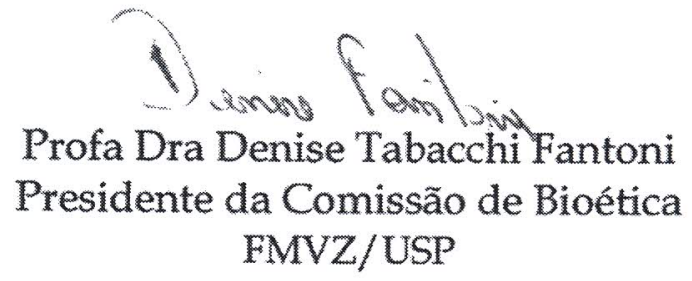


Folha de avaliação

Nome: BARRETO, Rodrigo da Silva Nunes

\section{Título:}

Dissertação apresentada ao Programa de Pós-Graduação em Anatomia dos Animais Domésticos e Silvestres da Faculdade de Medicina Veterinária e Zootecnia da Universidade de São Paulo para obtenção do título de Mestre em Ciências

Data:

Banca Examinadora

Prof. Dr. Instituição:

Assinatura: Julgamento:

Prof. Dr. Instituição:

Assinatura: Julgamento:

Prof. Dr. Instituição:

Assinatura: Julgamento: 


\title{
DEDICATÓRIA
}

\begin{abstract}
A Deus, pois tudo só é possível pela vontade Dele.
\end{abstract}

Ao meu pai, José Nunes Barreto, e minha mãe, Nilcéa da Silva Nunes Barreto. Vocês são minha base, meu porto seguro; sem vocês não teria concluído nem uma ínfima parte de meus sonhos. 


\section{AGRADECIMENTOS}

À Fundação de Amparo a Pesquisa do Estado de São Paulo (FAPESP) pelo auxílio financeiro para o desenvolvimento deste projeto de pesquisa.

Ao Prof. Dr. Flávio Vieira Meirelles, pela confiança depositada durante o desenvolvimento do projeto e pela orientação concedida durantes esses últimos anos, sempre me norteando nos momentos necessários.

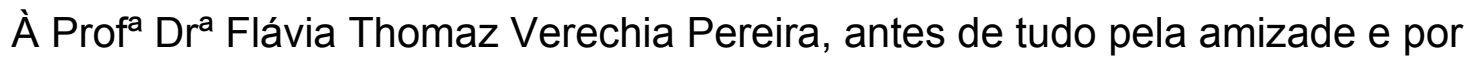
todos os ensinamentos durante esses anos. Lembre-se sempre, de que grande parte das minhas conquistas têm a sua participação.

À Profa ${ }^{\text {Dra }}{ }^{\mathrm{a}}$ Maria Angélica Miglino e aos Professores Doutores Carlos Eduardo Ambrósio (Caju), Felipe Perecin, Heidge Fukumasu pelos muitos esclarecimentos.

À Fabiana Fernandes Bressan (Martini), por ter me acolhido no LMMD, me ensinado, pelas discussões e diversas dúvidas esclarecidas, permitindo que meu projeto saísse do papel.

À $\mathrm{Dr}^{\mathrm{a}}$ Lilian Jesus de Oliveira, pela ajuda fundamental para o desenvolvimento dessa dissertação; por todas as madrugadas a fio no laboratório, principalmente na fase de finalização do projeto, por todas as "broncas" mais do que merecidas e pelas diversas injeções de ânimo.

À $\mathrm{Dr}^{\mathrm{a}}$ Lígia Garcia Mesquita, pela grande ajuda na parte final do projeto, que juntamente com o Prof. Dr. Luis Felipe Prada e Silva, permitiu a utilização do laboratório de Genômica Funcional.

À Prof ${ }^{a}$ Dra $^{a}$ Ester Silveira Ramos, e suas alunas Cristiana Libardi Miranda Furtado, Flávia Gaona de Oliveira Gennaro e Hélida Regina Magalhães. 
À Marília Mondin Thomaz Verechia pela indispensável revisão do manuscrito.

Aos meus amigos: Kelly, Juliano, Rafa, Fernanda, Annie, Anna e Celina por toda a ajuda, incentivo e companhia durante todos esses anos de mestrado.

À enorme equipe de amigos do LMMD, Naira, Juliana, Nina, Vanessa, Aline, Thiago, Reno, Marquinhos, Lindsay, Pedrinho, Laís, por toda companhia, apoio e incentivo.

Aos técnicos dos LMMD, Nilton, Márcia e Sílvia, por todo o apoio.

A todos os alunos de Pós-Graduação do Programa de Anatomia dos Animais Domésticos e Silvestres, pela convivência durante o cumprimento das disciplinas no campus da Universidade de São Paulo.

Por fim obrigado a todos, pois tem um pouco da ajuda de cada um nas páginas dessa dissertação. 


\section{RESUMO}

BARRETO, R. S. N. Ocorrência e mecanismos do microquimerismo fetal em gestações bovinas [Occurrence and mechanisms of fetal microchimerism in bovines pregnancies]. 2011. 68f. Dissertação (Mestrado em Ciências) - Faculdade de Medicina Veterinária e Zootecnia, Universidade de São Paulo, São Paulo, 2011.

Sucesso da gestação depende da adequada comunicação materno-fetal, que em algumas espécies têm um contato mais íntimo devido à capacidade migratória de populações de células trofoblásticas. Nos bovinos esse mecanismo é realizado pelas células trofoblásticas gigantes (CTGs), com invasão limitada até a lâmina basal do epitélio materno. Apesar dessa leve invasão das CTGs, é possível encontrar células fetais circulantes no sangue periférico da vaca gestante, levando ao microquimerismo fetal. Além de toda uma sinalização local e sistêmica e mudanças conformacionais, a migração das CTGs também é dependente da tolerância imunológica do epitélio materno que possui uma baixa expressão de MHC de classe I. Em contrapartida, o trofoblasto expressa MHC de classe lb para impedir a ativação das células natural killers uterinas (UNK) contra ele mesmo. Neste contexto, o objetivo desse trabalho foi estudar a ocorrência e contribuir para o entendimento dos mecanismos da migração celular na placenta bovina, com marcadores exclusivos do cromossomo $\mathrm{Y}$ e de um modelo de clone transgênico expressando a proteína GFP. A hipótese testada foi que o microquimerismo fetal observado mediante a detecção do gene TSPY no sangue periférico da vaca gestante de embrião macho, e de GFP nos tecidos placentários maternos, associado à expressão de MHC classe 1b (Qa2) na interface materno-fetal. Para tanto, 153 embriões produzidos por fertilização in vitro (FIV) foram transferidos, resultando em 34 embriões machos e 31 fêmeas no dia 62 de gestação, quando foi realizada a coleta de sangue periférico da receptora. Dentre estas gestações, foram selecionadas de 25 machos, 4 fêmeas e 5 perdas gestacionais (confirmadas no D39 por ultrassonografia) para detecção de TSPY. Também foram produzidas gestações de clones transgênicos, expressando GFP com 30, 60 e 90 dias que foram utilizadas para a detecção de mRNA e a proteína GFP. Nas gestações de FIV $60 \%$ dos embriões machos, $50 \%$ das fêmeas e $40 \%$ das perdas gestacionais foram positivos para TSPY. A detecção de TSPY nas gestações de fêmeas possivelmente é resultante da persistência do microquimerismo de 
gestações anteriores. Nas gestações de clones transgênicos, observou-se a presença de mRNA e proteína GFP no endométrio, também indicando migração nesta região ou o transporte da GFP, e outros conteúdos do trofoblasto, para o epitélio materno. Nos placentônios, usando anticorpo anti-GFP pode-se ver a marcação positiva tanto no trofoblasto como no epitélio materno, possivelmente decorrente de liberação das CTGs no estroma endometrial após a fusão. As CTGs, quando em formação sincicial, têm a sua expressão de GFP diminuída, o que também foi observado, utilizando-se anticorpo anti-Qa2 (antígeno murino para MHC classe lb). O epitélio materno e o trofoblástico também foram marcados para Qa2. Mediante as técnicas utilizadas, observamos que o microquimerismo pôde ser identificado nas gestações analisadas com o uso dos marcadores TSPY no sangue e o GFP nos tecidos placentários maternos. Este estudo mostra que na placenta bovina ocorre uma migração de células fetais além do epitélio materno e abre novas perspectivas para estudos das características da interação materno-fetal ainda pouco explorada nos bovinos.

Palavras-chave: Microquimerismo fetal, invasão trofoblástica, placentação bovina, células trofoblásticas gigantes, TSPY 


\section{ABSTRACT}

BARRETO, R. S. N. Occurrence and mechanisms of fetal microchimerism in bovines pregnancies [Ocorrência e mecanismos do microquimerismo fetal em gestações bovinas]. 2011. 68f. Dissertação (Mestrado em Ciências) - Faculdade de Medicina Veterinária e Zootecnia, Universidade de São Paulo, São Paulo, 2011.

The pregnancy success depends of adequate materno-fetal communication, that in some species are have a more intimate contact due migratory capacity of trophoblastic cells populations. In bovines, this mechanism is realized by trophoblast giant cells (TGC) with limited invasion until basal lamina of maternal epithelium. Besides this light invasion of TGCs, is possible to encounter circulate fetal cells in peripheral blood of pregnant cow, leading to fetal microchimerism. Beyond local and systemic sinalization and conformational changes, TGC migration is also dependent of immunologic tolerance of maternal epithelium that possess a downregulation of classe I MHC. In complement, the trophoblast express classe $\mathrm{Ib} \mathrm{MHC}$ to inhibit natural killers cells activation. In this context, the objective of this work was to study the occurrence and contribute for knowledge cellular migration mechanisms in bovine palcenta, with Y-specific markers and a model of transgenic clone expressing GFP. The tested hypothesis was that fetal microchimerism observed by detection od TSPY gene in peripheral blood of cow pregnant of male embryo, and of GFP in maternal placental tissues associated by expression of class lb MHC (Qa2) in materno-fetal interface. For this, 153 embryos produced by in vitro fertilization (IVF) were trasnfered, resulting in 34 male embryos and 31 female in day 62 of pregnancy, when recipient peripheral blood was collected. Among these pregnancies, 25 males, 4 females and 5 pregnancy losses (confirmed at 39 days of pregnancy by ultrassonography) was selected for TSPY detection. Also were produced pregnancies of transgenic cloned, embryos expressing GFP, with 30, 60 and 90 days of pregnancy that utilized for GFP mRNA and protein detection. In IVF pregnancies, $60 \%$ of male embryos, $50 \%$ of females and $40 \%$ of pregnancy losses were positive for TSPY. The detection of TSPY in female pregnancies possible is resultant of persistence of microchimerism of anterior pregnancies. In transgenic cloned pregnancies, was observed presence of GFP mRNA and protein in endometrium, also indicating migration in this region or GFP transport, and another trophoblast 
content, to maternal epithelium. In placentomes, using anti-GFP antibody, could be observed positive immunolabeling in trophoblast and maternal epithelium, possible due CTGs liberation in endometrial stroma after fusion. The CTGs, in syncytium formation, have a downregulation of GFP, that also be observed, utilizing anti-Qa2 antibody (murine antigen of classe $\mathrm{lb} \mathrm{MHC}$ ). The maternal and trophoblastic epithelium also was Qa2 immunolabed. By utilized techniques, microchimerism could be indentified in analyzed pregnancies with use of markers for TSPY in maternal blood and GFP in maternal placental tissues. This study show that in bovine placenta occurs fetal cell migration further maternal epithelium and show new perspectives for studies of materno-fetal interaction characteristics until under explored in bovines.

Key words: fetal microchimerism, trophoblast invasion, bovine placentation, trophoblast giant cells, TSPY. 


\section{LISTA DE FIGURAS}

Figura 1- Árvore filogenética dos mamíferos eutérios. Os eutérios são a união ramos Laurasiatheria (verde), Euarchontoglires (amarelo), Xenarthra e Afrotheria, os marsupiais são um grupo externo. Inscrições em azul são eutérios com placentação histiotrófica e em preto hemotrófica. Modelo filogenético adaptado de Vogel (2005).

Figura 2 - Fotografias "ex situ" em vista dorsal de útero bovino gestante, aos 60 dias, de concepto clonado e transgênico expressando GFP. A e C fluorescência natural sob luz ultravioleta. B e D mesmo campo de A e C, porém sob luz natural.

Figura 3 - Expressão relativa do mRNA do gene GFP no cório, placentônio e endométrio dos úteros gestantes utilizando a diferença entre os $\mathrm{Cts}(\mathrm{dCt})$ do gene GFP e o endógeno GAPDH...

Figura 4 - Western blotting para GFP (32kDa) em tecidos placentários de gestações transgênicas e clonadas. PPM - padrão de peso molecular; 1- placentônio 30dias; 2- endométrio 90 dias; 3- endométrio D30; 4- endométrio D60; 5placentônio D60.

Figura 5 - Imunohistoquímica para proteína verde fluorescente (GFP) em placentônio de gestação de concepto bovino transgênico e clonado aos 90 dias. Observar a intensa marcação no trofoblasto $(T)$, e epitélio materno $(E m)$, mais tênue no mesênquina $(M)$ e negatica no estroma endometrial $(E)$. Barra $=200 \mu \mathrm{m}$. .50

Figura 6 - Imunohistoquímica para proteína verde fluorescente (GFP) em placentônio de gestação de concepto bovino transgênico e clonado. As setas indicam as células trofoblásticas gigantes fundidas ou em processo de fusão com as células do epitélio materno (Em). Alguns sincícios são formados próximos a vasos maternos (Mv), como em d, porém sempre ocorre remodelamento do epitélio materno. A marcação é positiva para GFP nos tecidos fetais, sendo mais forte no trofoblasto ( $T$ ) e mais tênue no mesênquima (M), mas também pode ser observada no epitélio materno e marcação negativa no estroma endometrial (E). Observar marcação positiva mais fraca na gestação de 60 dias (a). Em a e f, 60 dias de gestação. Em b-e, 90 dias de gestação. Em f, controle negativo. Barra $=20 \mu \mathrm{m}$

Figura 7 - Imunohistoquímica para proteína verde fluorescente (GFP) em placentônio de gestação de concepto bovino transgênico e clonado com 
90 dias. As células trofoblásticas gigantes (setas) se aproximam e forçam um remodelamento do epitélio materno $(\mathrm{Em})$, tornando-o pavimentoso ao invés de colunar (a-c). Observar em a-d a marcação tanto citoplasmática como no interstício do epitélio materno. Também em $f$, presença de células trofoblásticas gigantes (círculo) aparentemente mononucleares, apresentando o volume citoplasmático maior e o nuclear menor que as outras células trofoblásticas gigantes. Em a-d,e imunohistoquímica para proteína verde fluorescente. Trofoblasto $(T)$, estroma endometrial $(E)$, mesênquima $(\mathrm{M})$ e vaso materno $(\mathrm{Vm})$. Barra $=10 \mu \mathrm{m}$.

Figura 8 - Fotomicrografia da reação de imunohistoquímica para GFP (a) e Qa2 (b) em placentônio de gestação de concepto bovino transgênico e clonado aos 90 dias. Observar o epitélio materno (Em), porém ao centro ocorre a degradação do epitélio materno $(\mathrm{Em})$ e várias células trofoblásticas gigantes em profundidades diferentes de invasão no trofoblasto $(T)$. As células trofoblásticas gigantes em contato direto com o epitélio materno apresentam marcação negativa tanto para GFP como para Qa2. Barra = $20 \mu \mathrm{m}$.

Figura 9 - Fotomicrografia da reação de imunohistoquímica para Qa2 em placentônio (a-d) e em cório $(e, f)$ de gestação de concepto bovino transgênico e clonado. As setas indicam as células trofoblásticas gigantes fundidas ou em processo de fusão, notar a ausência de marcação para Qa2 nessas células (a-d). Observar marcação positiva para o epitélio materno $(\mathrm{Em})$ e o trofoblasto $(T)$ nos placentônios e negativa no trofoblasto e mesênqüima do cório. Em a-c, 90 dias de gestação; em d-f, 60 dias de gestação. Em e, controle negativo. Barra $=20 \mu \mathrm{m} . \ldots \ldots \ldots \ldots \ldots . . . .54$

Figura 10 - Modelo hipotético da ocorrência de microquimerismo na placentação bovina. Em a, após fusão a célula trofoblástica gigante com o epitélio materno, ou a célula híbrida entra no vaso sanguíneo materno ou é fagocitada por um macrófago (localizado próximo ao epitélio materno) que entra em recirculação. Em b, a célula trofoblástica gigante degranula seu conteúdo celular antes da fusão celular. Em c, a célula trofoblástica gigante transporta parte de seu conteúdo citoplasmática por meio de exossomos. 


\section{LISTA DE TABELAS E QUADROS}

Tabela 1 - Número de embriões sexados por ultrassonografia transrretal (US) e positivos (pos) ou negativos (neg) por expressão de TSPY no sangue periférico da receptora. 44

Quadro 1 - Relação dos pares de primers, sequencia, temperatura para anelamento e tamanho do fragmento amplificado. 


\title{
LISTA DE ABREVIATURAS E SIGLAS
}

\author{
bPAG Glicoproteínas associadas a gestação \\ bPL Lactogênio placentário \\ bPRP1 Proteína relacionada à prolactina 1 \\ cDNA Ácido desoxirribonucléico complementar \\ cffDNA DNA fetal livre de célula, do inglês "cell-free fetal DNA" \\ CTB Células trofoblásticas gigantes \\ DNA - $\quad$ Ácido desoxirribonucléico \\ FIV Fertilização in vitro \\ GAPDH Gliceraldeído 3-fosfato desidrogenase \\ GFP Proteína verde fluorescente, do inglês "Green Fluorescente Protein" \\ HLAC Antígeno leucocitário humano C \\ HLAE Antígeno leucocitário humano E \\ HLAG Antígeno leucocitário humano G \\ MHC NC Molécula não clássica do complexo de histocompatibilidade comum \\ MHC Complexo de Histocompatibilidade Comum, do inglês "Major \\ histocompatibility complex" \\ mRNA Ácido ribonucléico mensageiro \\ NK Células natural killers \\ NK Células natural killers uterinas \\ P4 Progesterona \\ PBS Tampão sódio fosfato \\ PCR Reação de polimerase em cadeia
}


PED Antígeno de desenvolvimento embrionário de pré-imlantação, do inglês "Pre-implantation embryo development"

Qa2 Antígeno linfocitário Qa de região 2

SRY do inglês "sex-determining region"

TBS Tampão Tris-HCl

TSPY do inglês "Testis-specific protein, Y-encoded 


\section{SUMÁRIO}

1 INTRODUÇÃO

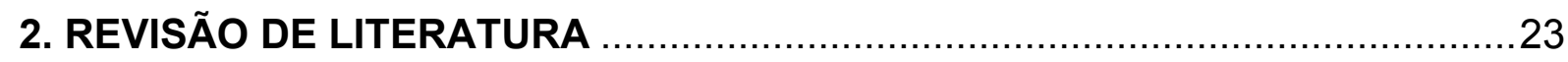

2.1 Evolução Filogenética dos Mamíferos Eutérios ……………………........23

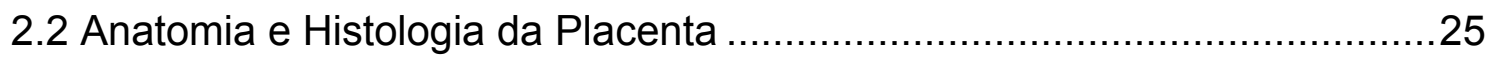

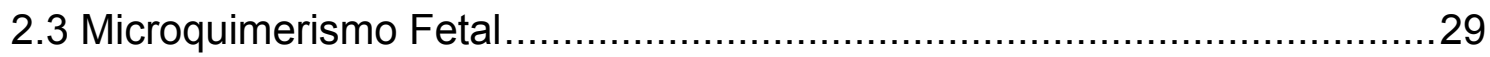

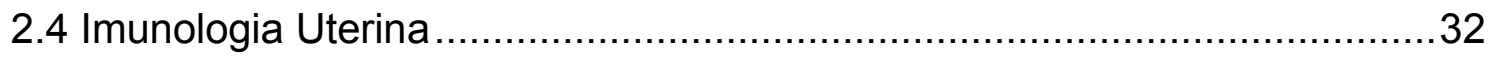

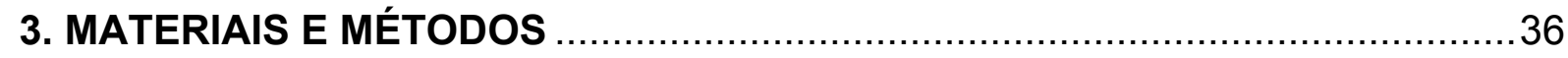

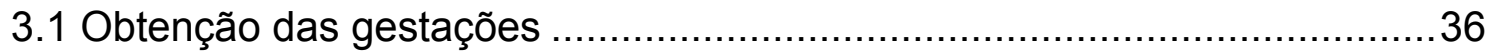

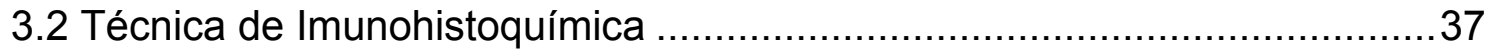

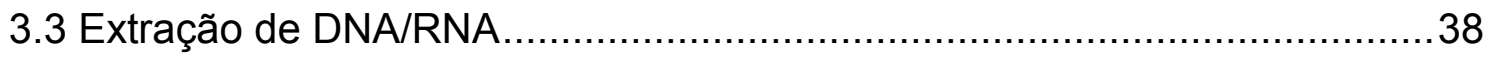

3.4 Reação de Polimerase em Cadeia (PCR) ……………………..............39

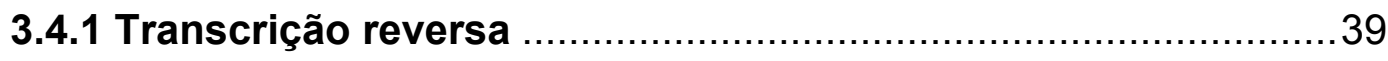

3.4.2 PCR quantitativo em Tempo Real ..............................................39

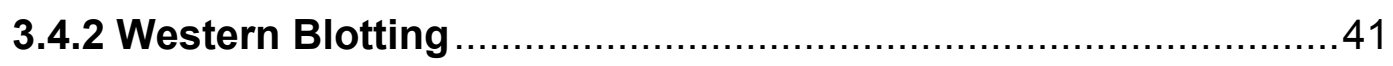

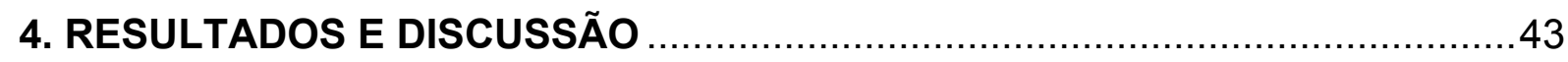

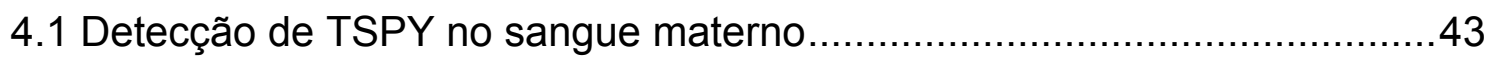

4.2. Mapeamento da interação materno-fetal pela GFP .................................45

4.2.1. Expressão de GFP nos tecidos materno e fetais...........................45

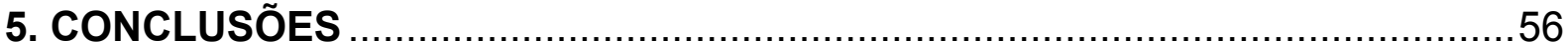

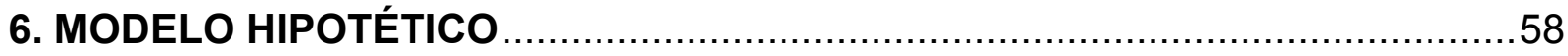

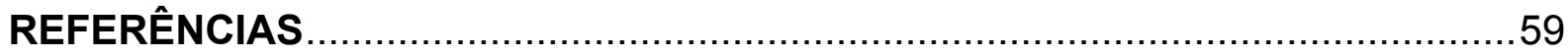




\section{INTRODUÇÃO}




\section{INTRODUÇÃO}

A comunicação adequada entre mãe e feto é crucial para o sucesso da gestação e ocorre por meio da placenta na maioria dos mamíferos. A placenta é um órgão transitório que secreta uma grande quantidade de moléculas importantes para a manutenção da gestação, tais como, estrógeno, progesterona e lactogênio placentário (MOSSMAN, 1987; BANKS, 1992; LEISER; KAUFMANN, 1994; KUMAR et al., 2007).

Muito do que sabe sobre os mecanismos envolvidos na comunicação entre mãe e feto são amplamente estudados em humanos e camundongos. Nestas espécies, a placenta é caracterizada pela alta capacidade de invasão das células trofoblásticas em direção ao tecido materno, nas quais os trofoblastos estão banhados em sangue materno, caracterizando a placenta como hemotrófica (LEISER; KAUFMANN, 1994).

Em bovinos, a placentação é classificada como sinepiteliocorial e caracterizada por possuir uma população de trofoblasto com propriedade migratória (WOODING, F. B. P. et al., 1996). Na placenta bovina, células trofoblásticas migram em direção ao tecido materno, fundindo-se com células do epitélio uterino e degranulando no estroma endometrial (WOODING, F.B., 1992). No entanto, não está bem elucidado se a migração de células fetais se limita ao epitélio materno ou não. A possibilidade de migração celular além do limite do epitélio caruncular e da membrana basal foi levantada após evidências da presença de DNA que codifica genes exclusivamente fetais circulantes no sangue materno. Hiendleder et al. (2003), mostraram que após aos 80 dias de gestação em bovinos é possível encontrar DNA mitocondrial fetal circulante na mãe. Em outro estudo, em uma gestação de embriões machos expressando o transgene caseína $\beta / \kappa$, foram encontrados tanto DNA da construção (transgene) quanto dos genes SRY (do inglês "sex-determining region $Y$ "), circulante no sangue de vacas gestantes de embriões machos sugerindo um possível microquimerismo materno-fetal como descrito em espécies com placentas mais invasivas (XI et al., 2006; TURIN et al., 2007b; TURIN et al., 2007a; WANG et al., 2010)

Uma característica das células trofoblásticas é a baixa expressão de proteínas do complexo de histocompatibilidade maior ( $\mathrm{MHC}$, do inglês "Major histocompatibility complex") o que as tornam mais susceptíveis à ação das células 
natural killers (NK). No entanto, a expressão de uma forma menos polimórfica do MHC de classe I, denominado como MHC de classe lb ou não-clássico (NC) foi descrita em algumas espécies (HUNT et al., 1985; GOGOLIN-EWENS et al., 1989; DONALDSON et al., 1990; KYDD et al., 1991). Em humanos essa molécula é conhecida como Antígeno Leucocitário Humano G (HLAG, do inglês "Human leukocyte antigen") e em murinos como Antígeno de Desenvolvimento Embrionário de Pré-Implantação (PED, do inglês "Pre-implantation embryo development"). Em bovinos, genes NC foram descritos (DAVIES et al., 2006) e estes possuem baixos níveis de expressão nos tecidos estudados, e na placenta têm sua expressão e função não conhecidas.

A avaliação da capacidade migratória do trofoblasto pode ser estudada com a utilização de animais transgênicos, nos quais a expressão de um gene exógeno consegue marcar células de origem fetais que pode ser detectado em vários tecidos maternos (BRESSAN et al., 2011).

Um exemplo é o cruzamento de fêmeas murinas, tipo selvagem (não transgênicas) com machos transgênicos expressando a proteína verde fluorescente (GFP, do inglês "Green fluorescent protein") para visualização de microquimerismo fetal e materno. Ainda esse modelo foi eficiente para avaliar o trânsito bidirecional de células fetais e maternas durante a gestação (VERNOCHET; CAUCHETEUX; KANELLOPOULOS-LANGEVIN, 2007).

Neste contexto, o objetivo desse trabalho foi estudar os mecanismos de migração celular na placenta bovina utilizando marcadores exclusivos do cromossomo $\mathrm{Y}$ e do modelo de clone transgênico, expressando a proteína GFP. Os objetivos específicos desse trabalho, bem como sua hipótese estão descritos abaixo:

1. Detectar o gene TSPY no sangue periférico materno aos 60 dias de gestação em bovinos.

Existem células fetais circulantes no sangue periférico materno aos 60 dias de gestação, indicando que o microquimerismo fetal já está instalado nesta fase crítica ao desenvolvimento fetal.

2. Identificar a proteína e mRNA do gene exógeno GFP nos tecidos placentários aos 60 e 90 dias.

Proteínas de origem fetal estão presentes nos tecidos maternos mostrando a interação materno-fetal placentomal e interplacentomal 
íntima, semelhante a encontrada em espécies com placentação consideradas invasivas.

3. Detectar a expressão de MHC classe $1 \mathrm{~b}$ nos epitélio materno e trofoblástico, de placentônios de gestações transgênicas entre os dias 60 e 90 de gestação.

As células trofoblásticas gigantes têm uma maior expressão de $M H C$ classe $1 b$ do que as demais células trofoblásticas. 
REVISÃO DE LITERATURA 


\section{REVISÃO DE LITERATURA}

Este capítulo tem como finalidade revisar a literatura recente sobre o microquimerismo fetal em bovinos, elucidando a anatomia e histologia uterina básica, o mecanismo migratório e os aspectos imunológicos relacionados à placentação bovina.

\subsection{EVOLUÇÃO FILOGENÉTICA DOS MAMÍFEROS EUTÉRIOS}

Os animais eutérios tiveram origem em um ancestral comum que apresentava uma placenta com potencial múltiplo, hemotrófica e histiotrófica (VOGEL, P., 2005). Deste ancestral ocorreu a evolução de quatro ramos, Afrotheria, Xenarthra, Euarchontoglires e Laurasiatheria (VOGEL, P., 2005). Na figura 1, os dois ramos inferiores (Afrotheria e Xenarthra) da evolução dos eutérios são compostos apenas por mamíferos com placentação hemotrófica (na qual a mãe tem pouco ou não tem controle do aporte sanguíneo fetal), enquanto nos dois ramos superiores (Euarchontoglires e Laurasiatheria) existem representantes tanto da placentação hemotrófica e como da histiotrófica (na qual os vasos maternos permanecem intactos e a mãe pode controlar o aporte sanguíneo direcionado ao feto) (VOGEL, P., 2005). O aparecimento de uma placenta epitéliocorial provavelmente ocorreu em resposta à pressão de evolução para o desenvolvimento de uma placenta menos invasiva e com transporte de substâncias entre mãe e feto de forma mais eficiente (LEISER et al., 1997), na qual há um aumento do controle materno do suprimento sanguíneo para o concepto (MESS; CARTER, 2007). Ainda a placenta epitéliocorial seria uma melhor barreira imunológica diminuindo a sensibilização do sistema imune materno a antígenos fetais (MOFFETT; LOKE, 2006).

Os mecanismos genômicos que induziram a diversificação nos eutérios ainda são desconhecidos, porém os genes que regulam o desenvolvimento são bastante conservados filogeneticamente entre os tipos placentários (KNOX; BAKER, 2008).

Em camundongos, durante a gestação inicial, a decídua e o disco placentário expressam principalmente genes de origem ancestral dos eucariotos. Na gestação 
mais tardia, a expressão gênica é mais específica de roedores. Na placenta humana, em semelhança, durante a gestação inicial há a expressão de genes ancestrais e mais tardiamente genes específicos de primatas (KNOX; BAKER, 2008).

Uma avaliação global, resultante dos projetos genoma, indicou que o genoma bovino é $21 \%$ mais semelhante ao humano quando comparado ao murino (THE BOVINE GENOME SEQUENCING AND ANALYSIS CONSORTIUM et al., 2009). Em adição, uma análise comparando os genes preferencialmente expressos na placenta, apesar da diferença na classificação placentária, humanos e bovinos apresentam 23 genes expressos comumente contra 16 entre camundongos e humanos (BARRETO et al., 2011). Dos 23 genes comuns entre humanos e bovinos, 22 tem ontologias associadas à atividade hormonal (BARRETO et al., 2011).

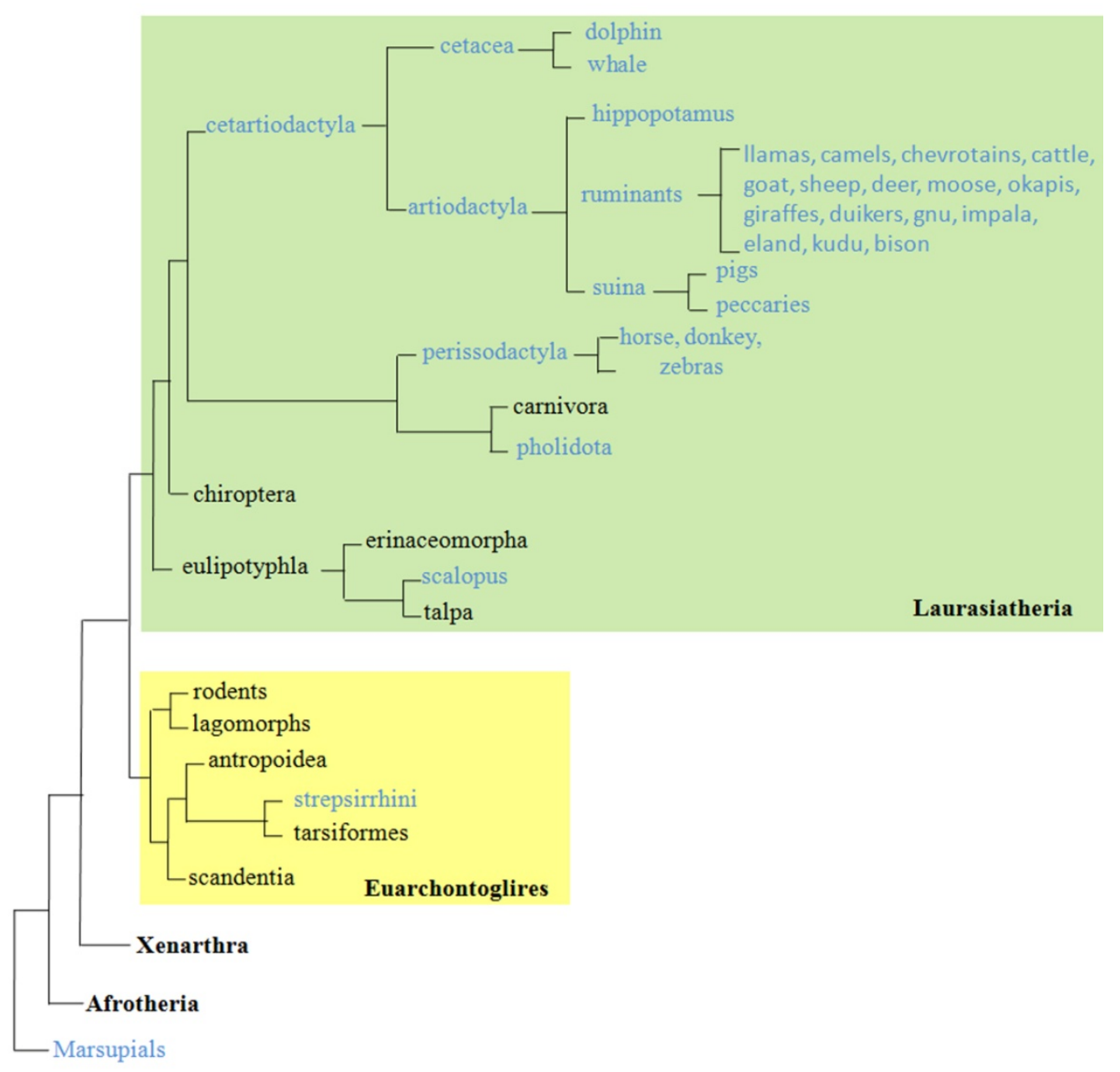

Figura 1- Árvore filogenética dos mamíferos eutérios. Os eutérios são a união ramos Laurasiatheria (verde), Euarchontoglires (amarelo), Xenarthra e Afrotheria, os marsupiais são um grupo externo. Inscrições em azul são eutérios com placentação histiotrófica e em preto hemotrófica. Modelo filogenético adaptado de Vogel (2005). 
A análise de grupos de genes de expressão placenta-específica mostrou que a distância relativa entre bovinos e murinos em relação aos humanos é similar, apesar de todas as diferenças morfológicas dos tipos placentários encontrados entre as espécies (BARRETO et al., 2011). Esta análise indica que, durante a evolução, a morfologia placentária se adaptou para uma melhor comunicação entre mãe e feto, sem alterar a expressão de genes cruciais ao sucesso da prenhez.

\subsection{ANATOMIA E HISTOLOGIA DA PLACENTA}

Nos mamíferos a diversidade morfológica da placenta é maior do que em qualquer outro órgão (MOSSMAN, 1987).

\subsubsection{Placentação bovina}

Quanto a sua anatomia macroscópica, a placenta bovina é caracterizada como cotiledonária, devido à presença de unidades funcionais chamadas placentônios, onde os tecidos maternos e fetais estão intimamente conectados (MOSSMAN, 1987; LEISER; KAUFMANN, 1994). Nas regiões placentomais, a interdigitação materno-fetal é vilosa, típica de ruminantes, as quais mergulham em criptas correspondentes formadas nas carúnculas (MOSSMAN, 1987; LEISER; KAUFMANN, 1994).

Nas regiões interplacentomais, a conexão materno-fetal é menos íntima, uma vez que o cório liso fica apenas em aposição ao epitélio uterino (LEISER; KAUFMANN, 1994). Por possuir uma maior conexão entre os tecidos, o placentônio é o local predominante de trocas de nutrientes e gases entre mãe e feto (MIGLINO; DIDIO, 1992). A placenta bovina inicialmente apresenta uma vascularização concorrente até o final do processo de placentação, passando para contracorrente ao longo da gestação (MIGLINO; DIDIO, 1992). A vascularização contracorrente é mais eficiente para as trocas difusionais que ocorrem na interface materno-fetal (KAUFMMAN e BURTON, 1994), visto que ocorre em animais cuja área contato é 
pequena em relação ao feto (LEISER; KAUFMANN, 1994). Esse tipo de vascularização pode explicar a troca eficiente de substâncias entre a mãe e o feto mesmo em regiões da placenta com conexão menos íntima, como na interplacentomal (MARQUES et al., 2007).

A placenta bovina pode ser classificada como sinepiteliocorial em virtude da presença de células com perfil migratório que ultrapassa a barreira epitelial, forma sincício com as células do epitélio uterino e, desta forma, aumenta o contato entre os tecidos maternos e fetais (MOSSMAN, 1987; LEISER; KAUFMANN, 1994).

A ampla aplicação de biotécnicas da reprodução na produção animal, especialmente a clonagem, demonstrou que a placentação é um dos processos mais comprometidos em conseqüência ao uso destas biotécnicas (MIGLINO et al., 2007). Por exemplo, durante a placentação de embriões bovinos clonados ocorrem marcantes alterações anatômicas que provavelmente contribuem para suas baixas taxas de nascimentos (em torno de 5\%) (MIGLINO et al., 2007; MEIRELLES et al., 2010). A maioria das perdas gestacionais de conceptos bovinos clonados ocorre entre 30 e 60 dias de gestação (WELLS, 2005). Frequentemente, estas perdas estão associadas a deficiências placentárias. Exatamente nesse período (de 40-60 dias de gestação), ocorre a transição da nutrição fetal vitelínica para placentária, sendo crucial para a sobrevivência do feto em desenvolvimento (ASSIS NETO et al., 2009). Ainda, em animais gestando embriões clonados, tanto no decorrer (HILL et al., 2000) como no final da gestação (HEYMAN et al., 2002), a placenta apresenta uma diminuição da vascularização, áreas hemorrágicas, hipoplasia placentária (MIGLINO et al., 2007), alterações no número, tamanho e formato dos placentônios, presença de hidroalantóide, e de malformações do cordão umbilical que são via de regra associados ao bezerro macrossômico ("Large offspring syndrome") (YOUNG; SINCLAIR; WILMUT, 1998; DE SOUSA et al., 2001).

\subsubsection{Placentação sinepiteliocorial}

A placenta epiteliocorial é caracterizada pela presença de todas as seis camadas de tecidos entre o sangue materno e o fetal, sendo elas: endotélio materno, estroma endometrial, epitélio materno, trofoblasto, mesênquima e endotélio 
fetal (LEISER; KAUFMANN, 1994; DANTZER, 1999). Diferentemente deste padrão, na placenta hemocorial encontrada em humanos, o trofoblasto é banhado pelo sangue materno em conseqüência da invasão de células trofoblásticas que ultrapassam a camada endotelial materna (LEISER; KAUFMANN, 1994).

Algumas adaptações encontradas em espécies com placenta epiteliocorial podem ser desenvolvidas no sentido de melhorar a comunicação entre mãe e feto. Por exemplo, a presença de pequenas áreas fagocitárias nos suínos e ruminantes e as células de origem fetal que invadem o epitélio uterino em éguas e ruminantes (CARTER; ENDERS, 2004; CARVALHO et al., 2006; CAZERTA et al., 2007; MIGLINO et al., 2007; PEREIRA et al., 2009).

Ainda, na placenta sinepiteliocorial é caracterizada a presença de migração de células trofoblásticas gigantes mono ou binucleadas em direção ao compartimento materno (WOODING, F. B. P. et al., 1996; DANTZER, 1999; 2002; CARTER; ENDERS, 2004; CARVALHO et al., 2006). Uma vez no compartimento materno, essas células se fundem com células do epitélio uterino formando um sincício (WOODING, F.B., 1992). A função e as conseqüências dessa migração ainda não são bem esclarecidas, porém sabe-se que essas células migratórias têm síntese específica de algumas moléculas cruciais ao sucesso da gestação (WOODING, F. B. P. et al., 1996; DANTZER, 1999; 2002; CARTER; ENDERS, 2004; CARVALHO et al., 2006).

\subsubsection{Células trofoblásticas binucleadas e migração celular em bovinos}

A presença de células trofoblásticas gigantes (CTG) é observada em estágios desde o dia 16 de gestação e persiste até o final (WOODING, F. B. P. et al., 1996). Essas células compõem $20 \%$ do epitélio coriônico fetal e originam-se a partir de células do trofoblasto mononuclear por mitose acitoquinética (WOODING, F. B. P. et al., 1996; LANG et al., 2004). A migração das células trofoblásticas binucleadas inicia-se durante a janela de implantação, ou seja, por volta dos 19-20 dias e persiste por todo o desenvolvimento até o termo (MACINTYRE et al., 2002).

As CTBs têm como principal função a síntese de esteróides, tais como, progesterona (P4) (VANSELOW; FURBASS; TIEMANN, 2008) e prostanóides e de 
proteínas, como lactogênio placentário (bPL) (WOODING, F. B.; BECKERS, 1987), proteína relaciona à prolactina 1 (bPRP1) e glicoproteínas associadas à gestação (bPAG) (ZOLI et al., 1992), fatores cruciais para a manutenção da gestação (WOODING, F. B. P.; FLINT, 1994; WOODING, F. B. P. et al., 1996).

Durante a migração, as CTB, assim como de todas as células epiteliais, seguem uma trajetória predeterminada limitada por alguns componentes da matriz extracelular (ALBERTS et al., 2008). Esse tipo de migração celular é mais complexo que a das células do tecido conjuntivo, uma vez que para adquirir motilidade devem previamente ficar independentes do epitélio original. A interação célula-célula nos epitélios é muito forte visto que estão conectadas à lâmina basal através de hemidesmossomas (ALBERTS et al., 2008), estrutura caracterizada pela interação dos filamentos intermediários de queratina ligadas às integrinas - domínio citosólico e as fibrilas de colágeno do tipo IV, existentes na lâmina basal, por meio de laminina - domínio extracitosólico (ROBERTS; HIB, 1998; ALBERTS et al., 2008). Porém, à medida que as células se programam e migram, as integrinas são primeiramente agrupadas na membrana plasmática e então organizadas em adesão focal que ancora o citoesqueleto de actina na matriz extracelular para regular o formato celular e migração (ARMANT, 2005). As integrinas normalmente se ligam com baixa afinidade para que as células não se tornem irreversivelmente unidas à matriz extracelular e sejam capazes de se mover (ZEILER et al., 2007; ALBERTS et al., 2008). A ativação da integrina $\beta 1$ leva à formação de adesões focais no epitélio caruncular na interface materno-fetal (BRIDGER et al., 2008).

Deste modo, as células trofoblásticas gigantes migram pelas junções aderentes, que diferentemente do hemidesmossas são conexões célula-célula através dos filamentos de actina e não dos filamentos intermediários, formando um anel contráctil na célula e é considerada uma conexão mais instável (ALBERTS et al., 2008).

Após a migração as células trofoblásticas gigantes se fundem apicalmente com as células unicelulares do epitélio materno via formação de pseudópodes formando um epitélio híbrido materno-fetal trinucleado, chamado sincício (MACINTYRE et al., 2002). Após a formação do sincício, as células híbridas entram em um processo de degeneração, reabsorção, ou degranulação do conteúdo citoplasmático no compartimento materno (NAKANO et al., 2001; MACINTYRE et al., 2002; PFARRER; HIRSCH; LEISER, 2003; LANG et al., 2004). Esta migração pode 
ser interpretada como uma invasão trofoblástica "restrita" ao epitélio uterino, não ultrapassando os limites da membrana basal.

\subsection{MICROQUIMERISMO FETAL}

A migração de células fetais para o organismo materno, ou seja, o microquimerismo fetal é um conceito bastante antigo, sendo originalmente descrito em um estudo publicado no ano de 1893, no qual descrevia a presença de células trofoblásticas no pulmão de uma gestante após sua morte por eclampsia (BIANCHI; LO, 2001). Mais tarde, a presença de células fetais circulantes foi descrita em mulheres grávidas de fetos masculinos que apresentavam linfócitos, com cariótipo 46, XY, em seu sangue periférico (WALKNOWSKA; CONTE; GRUMBACH, 1969), confirmando assim a hipótese da ocorrência natural de microquimerismo fetal.

Desde o trabalho de Walknowska et al (1969) muitos outros relataram a presença de várias populações de células fetais circulantes (eritrócitos nucleados, células trofoblásticas, leucócitos e células tronco) no sangue periférico de mulheres gestantes e a persistência destas em alguns órgãos após o parto (LO, 1994; BIANCHI et al., 1996; BIANCHI et al., 1997; BIANCHI; LO, 2001; FLORI et al., 2004; GADI; NELSON, 2007; DUBERNARD et al., 2008).

No entanto, a quantidade de células encontradas no sangue periférico é bastante limitada, podendo variar de 3 a 74 células em um volume de 15 a $40 \mathrm{ml}$ de sangue, conferindo uma relação de uma célula fetal nucleada para cada $10^{5}-10^{6}$ células maternas (BIANCHI et al., 1997).

Apesar do número de células fetais no sangue periférico da mãe ser restrito, existe uma correlação positiva entre o aumento do número destas células e gestação aneuplóidica (LO et al., 1994; BIANCHI et al., 1997). Por exemplo, em uma gestação com aneuploidia para o cromossomo 21 , onde $74 \%$ das células circulantes no sangue periférico da mãe eram de origem fetal (LO, 1994), ou mesmo um aumento de quase nove vezes em relação às gestações normais (BIANCHI et al., 1997).

Alterações similares da relação entre células fetais e maternas circulantes na mãe também foram relatadas em gestações com pré-eclampsia, nas quais se pode 
encontrar um número maior de células trofoblásticas em esfregaços de sangue venoso uterino (CHUA et al., 1991). O aumento do número de células fetais também está correlacionado com gestações onde o feto tem restrição de crescimento ou com presença de poli-hidroâmnio (BIANCHI; LO, 2001), ocorrência muito comum em gestações de bovinos clonados (MIGLINO et al., 2007).

A persistência dessas células fetais no organismo da mãe pode durar décadas após a gestação (BIANCHI et al., 1996). Especula-se também a relação entre o microquimerismo fetal e a prevalência de doenças auto-imune em mulheres (BIANCHI; LO, 2001). Células fetais são recrutadas para o estroma do tumor de glândulas mamárias (DUBERNARD et al., 2008) e estão presente nos carcinomas mamários em mulheres (GADI; NELSON, 2007).

\subsubsection{DNA fetal livre de célula}

A pequena quantidade de células fetais no sangue materno promoveu a busca de outra fonte não invasiva de material genético fetal, o DNA fetal livre de células (cffDNA, do inglês "cell free fetal DNA") (BIANCHI; LO, 2001). O cffDNA foi inicialmente detectado no plasma materno utilizando um gene específico do cromossomo Y (SRY, do inglês "sex-determining region Y") (LO et al., 1997).

A concentração relativa de cffDNA no plasma materno é relativamente 2 a 3 vezes maior que as células fetais da fração celular no sangue materno (LO et al., 1998). Todavia, o cffDNA é rapidamente eliminado após o parto, possivelmente sendo eliminado na filtração renal, uma vez que cffDNA pode ser detectado na urina (BOTEZATU et al., 2000).

Em humanos, há evidências que suportam a hipótese de que o cffDNA presente no plasma sanguíneo da mãe é vestígio de células fetais circulantes que sofreram apoptose na circulação materna (BIANCHI; LO, 2001). Em gestações com aneuploidia, a taxa de células fetais circulantes em processo apoptótico é duas vezes maior que em gestações normais e, consequentemente levando a uma maior quantidade de cffDNA (BIANCHI; LO, 2001). 


\subsubsection{Microquimerismo em bovinos}

Apesar da invasão trofoblástica em bovinos ser considerada restrita ao epitélio uterino, e a possibilidade do microquimerismo fetal em bovinos ter sido descartada por Kadokawa et al (1996), ele foi originalmente descrito por Xi et al (2006) e posteriormente confirmado pelo mesmo grupo, usando um número maior de animais (WANG et al., 2010). Xi et al (2006) e Wang et al (2010) utilizaram o gene SRY como marcador de cffDNA presente no plasma sanguíneo da vaca em vários estágios da gestação.

Turin et al (2007b; 2007a) foram os primeiros a descrever a presença de células fetais circulantes durante e após a gestação de conceptos transgênicos e de monta natural utilizando como marcador outro gene específico do cromossomo $\mathrm{Y}, \mathrm{O}$ Y-S4 (proteína ribossomal ligada ao Y).

Recentemente outro gene específico do cromossomo $Y$ também vem sendo usado como ferramenta para a sexagem de embriões bovinos (LEMOS et al., 2005). Esse gene conhecido como TSPY (do inglês "testis-specific protein, Y-encoded") possui várias cópias no cromossomo $\mathrm{Y}$, podendo variar 20 a 40 em humanos e de 50 a 200 nos bovinos (JAKUBICZKA; SCHNIEDERS; SCHMIDTKE, 1993; VERKAAR et al., 2004; HAMILTON et al., 2009). O gene BRY é presumido como tendo a mesma origem que o TSPY, pois ambos contêm seqüências homólogas, porém provavelmente pertence a uma subfamília afuncional e apresenta cerca de 1200 cópias nos machos e 100 nas fêmeas (VOGEL, T. et al., 1997b; VOGEL, T. et al., 1997a; VOGEL, T.; SCHMIDTKE, 1998).

Apesar do grande número de cópias do gene TSPY facilitar a detecção de pequenas quantidades de material fetal no sangue materno, ele não seria um gene de eleição para extrapolar a correlação entre quantidade de DNA fetal circulante e anormalidades fetais ou placentárias em bovinos devido sua variação em número de cópias mesmo dentre indivíduos de uma mesma raça (HAMILTON et al., 2009).

Em bovinos, os principais interesses na investigação atual do microquimerismo são a sexagem da gestação ou a identificação de material transgênico em uma receptora de gestação de concepto transgênico. Porém um novo foco pode ser utilizado para associar a identificação de células fetais circulantes no sangue periférico da mãe com o sucesso da gestação, assim como 
em humanos está associado a pesquisas com aneuploidias e pré-eclampsia (LO et al., 1994; BIANCHI et al., 1997).

\subsection{IMUNOLOGIA UTERINA}

Pouco se sabe sobre a imunologia uterina em bovinos. Um sistema imune funcional é necessário, pois o útero é exposto constantemente a microorganismos. Uma vez que, no lúmen do útero bovino foram encontradas bactérias imediatamente após o parto em quase todas as vacas (FOLDI et al., 2006).

O útero da vaca é um local imunocompetente que pode gerar uma resposta imune à infecções recrutando leucócitos e produzindo citocinas (ROSBOTTOM et al., 2008). Em ovelhas, com placentação muito semelhante, aloenxertos expressando MHC clássico foram prontamente rejeitados quando inseridos em úteros (HANSEN et al., 1989).

Durante o ciclo estral, na vaca, células positivas para o MHC de classe II são amplamente distribuídas no estroma endometrial (COBB; WATSON, 1995), apresentando um acúmulo maior, principalmente linfócitos e macrófagos, próximo ao epitélio luminal do que no estroma glandular. Os macrófagos são limitados ao estroma endometrial, sendo ausentes no epitélio luminal ou glandular, sendo que o acúmulo dos macrófagos próximo as glândulas uterinas é raro (COBB; WATSON, 1995). Do meio até ao final da gestação, ocorre um aumento de células expressando MHC de classe II no endométrio da região interplacentomal comparada à placentomal (LOW et al., 1990).

Em um modelo de gestação unilateral, onde ovelhas tiveram os conceptos cirurgicamente restringidos a apenas um corno uterino, houve acúmulo de macrófagos no corno uterino gestante e no não gestante, mostrando uma sinalização sistêmica para recrutamento destas células (TEKIN; HANSEN, 2004). Porém no corno não gestante a quantidade de macrófagos era menor, indicando a importância de uma sinalização local (TEKIN; HANSEN, 2004).

Não se tem conhecimento se, no endométrio bovino durante a gestação, ocorre um influxo de células NK como em humanos e camundongos (CROY et al., 2006; MOFFETT; LOKE, 2006). As células NK uterinas bovinas (NKp46 ou CD335) 
foram encontradas no septo caruncular e no placentônio após a infecção experimental por Neospora canis em vacas gestantes (ROSBOTTOM et al., 2008). No útero de ruminantes, a única evidência funcional da presença de células NK foi a presença de linfocinas ativadas para função de destruição em linfócitos no epitélio uterino depois da estimulação por interferon gama (IFNG) e interferon tau (IFNT) (TEKIN; HANSEN, 2004).

\subsubsection{Expressão de MHC no trofoblasto}

A expressão de antígenos paternos pelo trofoblasto é geralmente suprimida em todas as espécies examinadas (HUNT et al., 1985; GOGOLIN-EWENS et al., 1989; DONALDSON et al., 1990; KYDD et al., 1991). A perda de expressão do MHC na placenta reduz a exposição do sistema materno a antígenos paternos (MOFFETT-KING, 2002). Porém torna o trofoblasto susceptível à lise pelas células NK (HEEMSKERK et al., 2005). Por essa razão, antígenos do MHC não clássicos são extremamente monomórficos e expressos no trofoblasto (BULMER; BILLINGTON; JOHNSON, 1984). Por exemplo, em humanos, o trofoblasto expressa o HLAC (TILBURGS et al., 2009), HLAE e HLAG (HUNT; PETROFF; BURNETT, 2000; ISHITANI et al., 2003; HVIID, 2006).

Na vaca, o tecido coriônico do placentônio é negativo para o MHC de classe I, embora o cório da região interplacentomal possa expressar MHC de classe I nos últimos quatro meses de gestação (LOW et al., 1990; DAVIES; FISHER; SCHLAFER, 2000; DAVIES et al., 2004).

O melhor entendimento dos efeitos da expressão normal versus a anormal de MHC teve uma grande contribuição com o desenvolvimento das tecnologias de reprodução assistidas, como inseminação artificial, produção de embrião in vitro e a transferência de nuclear de células somática.

Por exemplo, quando há uma expressão anormal de MHC de classe I ocorre aborto espontâneo, isso é particularmente observado entre os dias 30 a 90 dias de gestação (EDWARDS et al., 2003), exatamente no período (transição da nutrição vitelínica para a placentária) onde ocorrem as maiores perdas nesses tipos especiais de gestação. Nas gestações de fetos clonados, a expressão de MHC de classe I é 
predominantemente não clássica (DAVIES et al., 2004), e foi detectada aos 36 dias de gestação (DAVIES et al., 2004; DAVIES et al., 2006). Essas proteínas não clássicas do MHC de classe I expressas são possivelmente homólogas ao HLAG humano que pode regular a célula NK e a função do macrófago (LI et al., 2009). 
MATERIAIS E MÉTODOS 


\section{MATERIAIS E MÉTODOS}

\subsection{Obtenção das gestações}

Para identificação do gene TSPY, foram transferidos 153 embriões produzidos por fertilização in vitro em uma central comercial. No dia 62 de gestação, após a confirmação do sexo por ultrassonografia transrretal, foram coletadas amostras de sangue da veia caudal das receptoras. Dos 153 embriões transferidos, 65 chegaram aos 62 dias gestação, destes 34 eram machos e 31 fêmeas. Para o estudo foram então selecionadas 25 gestações de macho, 4 de fêmeas além de 5 perdas gestacionais previamente detectadas ao exame ultrassonográfico aos 39 dias de gestação porém com sexo desconhecido.

As gestações de conceptos bovinos transgênicos foram produzidas por transferência nuclear de célula somática. As células doadoras de núcleo utilizadas foram de uma linhagem de fibroblastos de um feto bovino macho transduzidos com um vetor lentiviral carreando o gene da proteína verde fluorescente. Inicialmente foi produzida uma gestação de 30 dias e o feto foi utilizado para a cultura de fibroblastos e realizar a reclonagem e obtenção de mais uma gestação de 30 dias, três de 60 dias e duas de 90 dias. O lentivírus, métodos de transfecção das células, clonagem e reclonagem foram realizados segundo Bressan et al. (2011).

Anteriormente à recuperação das gestações, por ovariossalpingohisterectomia, foi coletado sangue da veia caudal de cada receptora. Os úteros gestantes foram transportados em gelo para o laboratório, onde foi realizada uma incisão na linha anti-mesometrial do perimétrio e miométrio no terço médio do corno uterino gestante expondo membranas, endométrio e o embrião/feto.

Foram coletadas amostras de placentônio, carúncula e endométrio (região intercaruncular), cotilédones, cório liso, alantóide e âmnio (Figura 2). Cada amostra foi preservada em nitrogênio líquido ou fixados em solução aquosa de paraformaldeído $4 \%$ em tampão sódio fosfato (PBS) a 0,1 M pH 7,4. Após a fixação, o material foi desidratado em uma série de banhos em solução de etanol em concentrações crescentes (de 70 a 100\%), diafanizado em xilol, seguido de impregnação e inclusão em resina similar a parafina $\left(\right.$ Histosec $\left.^{\circledR}\right)$. 
Amostras de úteros gestantes de monta natural ou inseminação artificial, grupo controle, foram coletadas em abatedouros frigoríficos da região de Dracena e Pirassununga, SP, em períodos gestacionais e quantidades correspondentes às gestações de conceptos clonados transgênicos, seguindo o mesmo modo de coleta, preservação e processamento.

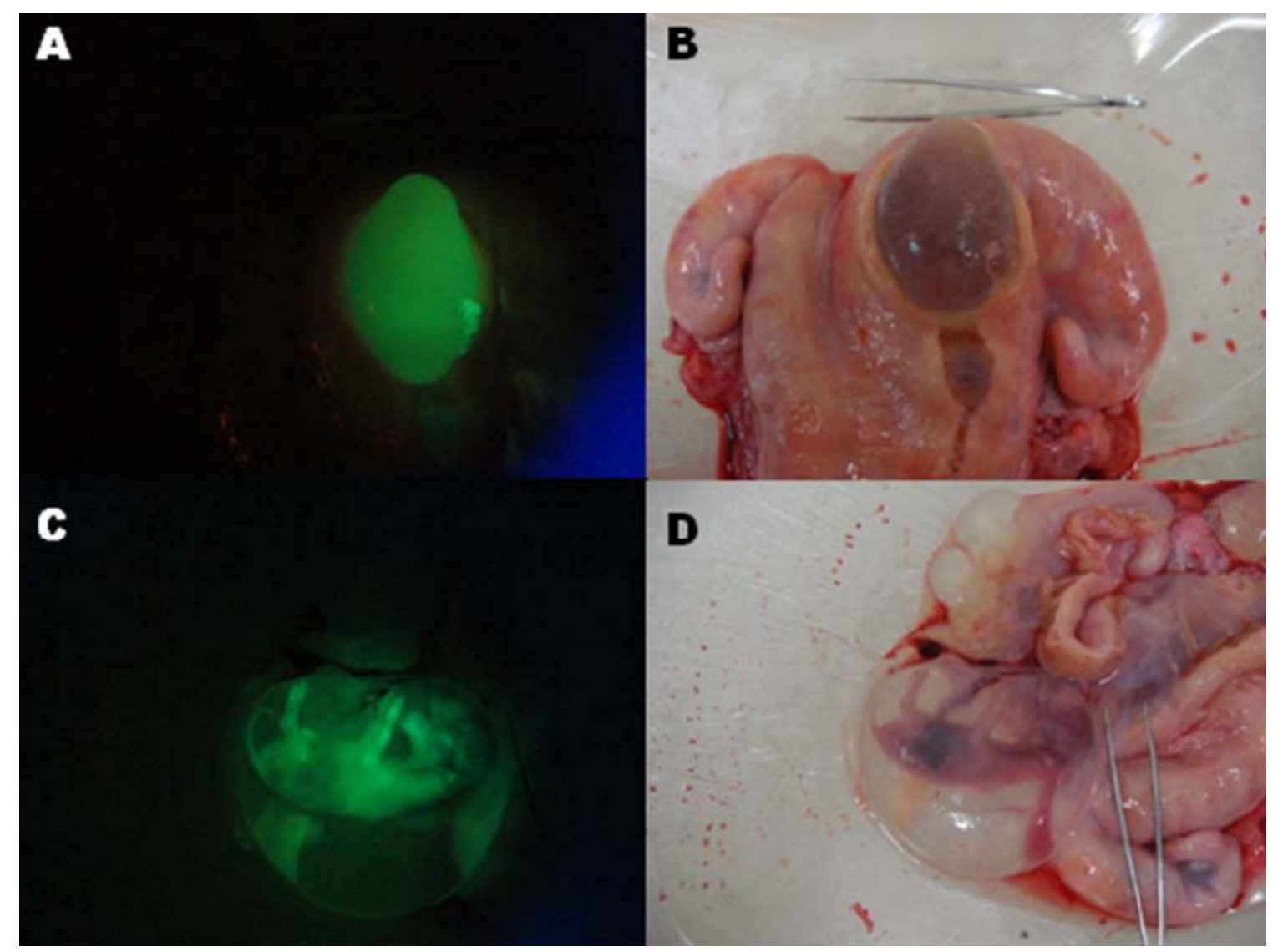

Figura 2 - Fotografias "ex situ" em vista dorsal de útero bovino gestante, aos 60 dias, de concepto clonado e transgênico expressando GFP. A e C fluorescência natural sob luz ultravioleta. $\mathrm{B}$ e $\mathrm{D}$ mesmo campo de $\mathrm{A}$ e $\mathrm{C}$, porém sob luz natural.

\subsection{TÉCNICA DE IMUNOHISTOQUÍMICA}

A identificação da Proteína Verde Fluorescente (GFP) em placentônios de gestações transgênicas e clonadas com 60 e 90 dias foi realizada utilizando os anticorpos anti-GFP (Living Colors GFP Monoclonal Antibody - Clontech, cat.\# 632375). A detecção do antígeno do MHC classe $1 \mathrm{~b}$ específico de murinos foi realizada usando o anticorpo anti-Qa2 (eBiosciences, cat, \# 11-5996). 
As secções de 4-5 $\mu \mathrm{m}$ foram desparafinizados em xilol e reidratados em série decrescente de etanol. O desmascaramento antigênico foi realizado pelo aquecimento dos cortes em tampão citrato $(0,384 \mathrm{~g}$ de ácido cítrico monohidratado; 2,352g de citrato de sódio tribásico diidratado; $1 \mathrm{~L}$ de água destilada, $\mathrm{pH} 6,0$ ) por 15 minutos em forno de microondas. A atividade de peroxidase tecidual endógena foi bloqueada pela incubação em solução de peróxido de hidrogênio a 3\% em tampão Tris- $\mathrm{HCl} 1 \mathrm{M}$, pH 7,5 (TBS, 60,57g de Tris para 500mL de água ultrapura) por 30 minutos. Para o bloqueio de ligações inespecíficas, os cortes foram incubadas com soro de cabra a $10 \%$ em TBS por 30 minutos. O anticorpo primário foi diluído a $0,2 \mathrm{mg} / \mathrm{mL}$ em tampão TBS contendo $1 \%$ de soro de cabra e incubado "overnight" a $4^{\circ} \mathrm{C}$ em câmara úmida. Paralelamente, cortes foram incubadas na mesma concentração com anticorpo irrelevante para o controle de isotipo (lgG).

Após incubação com o anticorpo primário e todas as lavagens dos cortes foram realizadas com TBS contendo $1 \%$ de soro de cabra. A reação foi visualizada por meio do kit polivalente Dako-advance HRP Link (cat. \# K4069, Dako, EUA..) de acordo com a recomendação do fabricante. A reação foi revelada por precipitação de 3,3'-diaminobenzidine (DAB Peroxidase Substrate Kit, 3,3'-diaminobenzidine, cat. \# SK-4100). Para finalizar os cortes foram contra-corados com hematoxilina, desidratados, diafanizados e as lâminas montadas para análise sob microscopia de luz.

\subsection{EXTRAÇÃO DE DNA/RNA}

O DNA e RNA das amostras de placentônio, carúncula e cório foram extraídas utilizando o kit Allprep (Qiagen, cat. \# 80204) ou RNAeasy (Qiagen, cat. \# 74104) segundo as recomendações do fabricante.

Para as amostras de região intercaruncular a extração do RNA total foi realizada com homogenatos de Trizol de acordo com as instruções do fabricante. 


\subsection{REAÇÃO DE POLIMERASE EM CADEIA (PCR)}

\subsubsection{Transcrição reversa}

O RNA foi incubado por 5 minutos a $70^{\circ} \mathrm{C}$ com $0,5 \mu \mathrm{L}$ de hexâmeros randômicos $\left(\mathrm{pd}(\mathrm{N})_{6}\right.$ Random Hexamer, Amershan Biosciences, Piscataway, NJ, EUA; $0,5 \mu \mathrm{L}$ ) e imediatamente resfriado a $4^{\circ} \mathrm{C}$, para adição de $0,5 \mu \mathrm{L}$ da enzima de trasncriptase reversa (SuperScript II, Invitrogen) e reagentes: tampão $5 x(2 \mu \mathrm{L})$, $\mathrm{MgCl}_{2}$ (3mM), 0,5 mM de cada dNTP, 0,5 $\mu \mathrm{L}$ de inibidor de RNase (RNase OUT ${ }^{\mathrm{TM}}$ Recombinant Ribonuclease Inhibitor, Invitrogen ${ }^{\mathrm{TM}}, 40 \mathrm{U} / \mu \mathrm{L}$ ) em volume final de 4,7 $\mu \mathrm{L}$ de solução para $5 \mu \mathrm{L}$ de RNA. As amostras foram incubadas a $42^{\circ} \mathrm{C}$ por 60 minutos, aquecidos a $70^{\circ} \mathrm{C}$ por 15 minutos para inativação da enzima e armazenadas $\mathrm{a}-20^{\circ} \mathrm{C}$ até o momento de uso.

\subsubsection{PCR QUANTITATIVO EM TEMPO REAL}

As amplificações foram realizadas em termociclador para PCR em tempo real (Applied Biosystems, 7500 Real Time PCR System).

Nas reações para quantificação do gene GFP e gliceraldeído 3-fosfato desidrogenase (GAPDH), foram utilizados oligonucleotídeos iniciadores e sondas Taqman $®$, sintetizadas pela Applied Biosystems. Os oligonucleotídeos iniciadores e sondas dos referidos genes estão apresentadas no quadro 1. Nas reações de amplificação, foi utilizado TaqMan® 2x PCR Master Mix (Applied Biosystems, Foster City, CA, EUA), 0,9 $\mu \mathrm{M}$ de cada oligonucleotídeo iniciador e 0,25 $\mu \mathrm{M}$ de sonda TaqMan $®$ em reação de $20 \mu \mathrm{L}$. A reação teve início com incubação a $50^{\circ} \mathrm{C}$ por 2 minutos, seguida de desnaturação a $95^{\circ} \mathrm{C}$ por 10 minutos e 50 ciclos de $95^{\circ} \mathrm{C}$ por 2 minutos e $60^{\circ} \mathrm{C}$ por 1 minuto. Cada amostra foi avaliada em triplicata para cada gene. Toda reação de PCR continha um controle negativo. 
A análise estatística realizada para avaliar a expressão relativa de GFP entre os tecidos placentários foi a do método de $2^{\text {-ddCT }}$ segundo Livak \& Schimittegen (2001).

Para a análise qualitativa do gene TSPY foi utilizada a técnica de PCR nested, que consiste na realização de duas reações de PCR seguidas, com pares de primes diferentes para a mesma seqüência.

Na primeira reação foram utilizados $2,5 \mu \mathrm{L}$ de tampão $10 \mathrm{X}, 0,5 \mu \mathrm{L}(10 \mathrm{mM}) \mathrm{de}$ dNTPs, $0,75 \mu \mathrm{L}(25 \mathrm{mM})$ de $\mathrm{Mg}^{2+} \mathrm{Cl}, 0,5 \mu \mathrm{L}$ de primer senso (TSPYext_s), $0,5 \mu \mathrm{L}$ de primer consenso (TSPYext_as), $1 \mu \mathrm{L}(100 \mathrm{ng} / \mu \mathrm{L})$ de DNA e $0,2 \mu \mathrm{L}$ de Taq polimerase e água DEPC suficiente para completar um volume total de $25 \mu \mathrm{L}$. As condições da PCR foram as seguintes: $94^{\circ} \mathrm{C}$ por 5 minutos para desnaturação inicial, 35 ciclos de desnaturação a $94^{\circ} \mathrm{C}$ por 45 segundos, anelamento a $60^{\circ} \mathrm{C}$ por 45 segundos e extensão a $72^{\circ} \mathrm{C}$ por 45 segundos, com uma extensão final a $72^{\circ} \mathrm{C}$ por 10 minutos. Na segunda reação foi utilizado Power SYBR Green ${ }^{\circledR}$ OCR MAster Mix (Applied Biosystems) e 0,5 mM de cada par de nucleotídeos iniciadores, em reação de $20 \mu \mathrm{L}$. As condições de termociclagem incluíram um passo inicial a $50^{\circ} \mathrm{C}$ por 2 minutos, seguida de desnaturação a $95^{\circ} \mathrm{C}$ por 10 minutos e 35 ciclos de $95^{\circ} \mathrm{C}$ por 15 segundos, $57^{\circ} \mathrm{C}$ por 45 segundos e $60^{\circ} \mathrm{C}$ por 1 minuto. A curva de dissociação foi iniciada em $60^{\circ} \mathrm{C} \mathrm{com}+0,1^{\circ} \mathrm{C}$ de incremento até atingir $95^{\circ} \mathrm{C}$.

\begin{tabular}{|c|c|c|c|}
\hline Primer & Sequência $\left(3^{\prime} \rightarrow 5^{\prime}\right)$ & $\mathrm{T}^{\circ} \mathrm{C}$ anelamento & Tam \\
\hline $\begin{array}{l}\text { TSPYext_S } \\
\text { TSPYext_as }\end{array}$ & $\begin{array}{l}\text { CCCGCACCTTCCAAGTTGTG } \\
\text { AGAAGACGGTGGAGGAGCA }\end{array}$ & $60^{\circ} \mathrm{C}$ & $325 \mathrm{pb}$ \\
\hline $\begin{array}{l}\text { TSPYint_S } \\
\text { TSPYint_as }\end{array}$ & $\begin{array}{l}\text { CATCGTGGAGGAGGTGGAGGTT } \\
\text { TTGTCACCAGCAGTTGTCACG }\end{array}$ & $64^{\circ} \mathrm{C}$ & $152 \mathrm{pb}$ \\
\hline $\begin{array}{l}\text { GAPDH_s } \\
\text { GAPDH_as } \\
\text { GAPDH_sonda }\end{array}$ & $\begin{array}{l}\text { AAGGCCATCACCATCTTCCA } \\
\text { CCACTACATACTCAGCACCAGCAT } \\
\text { AGCGAGATCCTGCCAACATCAAGTGG }\end{array}$ & $60^{\circ} \mathrm{C}$ & $75 \mathrm{pb}$ \\
\hline $\begin{array}{l}\text { eGFP_s } \\
\text { eGFP_as } \\
\text { eGFP_sonda }\end{array}$ & $\begin{array}{l}\text { CCACATGAAGCAGCACGACTT } \\
\text { TACGTCCAGGACCGCACC } \\
\text { TTCAAGTCCGCCATGCCCGAA }\end{array}$ & $60^{\circ}$ & $43 \mathrm{pb}$ \\
\hline
\end{tabular}

Quadro 1 - Relação dos pares de primers, sequencia, temperatura para anelamento e tamanho do fragmento amplificado. 


\subsubsection{Western Blotting}

Amostras de endométrio intercaruncular (EIC) foram retiradas do nitrogênio líquido e pesadas, obtendo-se um total de 2 gramas. Posteriormente, os fragmentos de EIC, juntamente com a solução de extração (2 gramas da amostra $+20 \mathrm{~mL}$ de solução de extração), foram macerados para a solubilização da fração protéica e centrifugadas para remoção de fragmentos teciduais. A proteína foi quantificada pelo ensaio colorimétrico "Bradford" e análise de western blotting foi realizada de acordo com (JOUSAN; OLIVEIRA; HANSEN, 2008) com algumas modificações. Resumidamente, $100 \mu \mathrm{g}$ de proteína foi diluída em volume igual de solução tampão de Tris-HCl $125 \mathrm{mM}$ (pH 6,8) contendo 10\% Dodecil Sulfato de sódio (SDS), 20\% de sacarose, e $5 \%$ de 2 -mercaptoetanol. As amostras foram desnaturadas a $100^{\circ} \mathrm{C}$ por 5 minutos e separadas em um gel de poliacrilamida (SDS-PAGE) $12 \%$ em solução Tris- $\mathrm{HCl}$ e transferidas para uma membrana PVDF (do inglês: Polyvinylidene Fluoride) por eletroforese. A membrana foi incubada "overnight" em solução de TBS$\mathrm{T}$ (10 mM Tris pH 7.6, 0.9\% de $\mathrm{NaCl}$ e $0.3 \%$ de Tween-20) contendo $5 \%$ de leite em pó desnatado (TBT-TB). Após as lavagens, a membrana foi incubada com anticorpo monoclonal anti-GFP (Living Colors GFP Monoclonal Antibody - Clontech, cat.\# 632375) diluído a 1:1000 em TBT-TB por 6h em temperatura ambiente, lavada e incubada com o anticorpo secundário anti-IgG de camundongo conjugado com HRP (do inglês, "horseradish peroxidase") por 90 minutos. Após lavagens adicionais, a reação foi revelada por precipitação de 3,3'-diaminobenzidine (DAB Peroxidase Substrate Kit, 3,3'-diaminobenzidine, cat. \# SK-4100) até o aparecimento das bandas específicas. 
RESULTADOS E DISCUSSÃO 


\section{RESULTADOS E DISCUSSÃO}

Para o sucesso da prenhez é essencial o estabelecimento da fina sintonia da tolerância do sistema imune materno frente aos antígenos fetais. No início da gestação, a tolerância materna tem que ser alta o suficiente para permitir a implantação do embrião e a placentogênese, porém sem comprometer a integridade e saúde da mãe. Esse conceito é a tese central da teoria do conflito parental, onde, genes expressos paternalmente maximizam o desenvolvimento fetal aumentando o suporte nutricional do feto em detrimento da saúde da mãe, por exemplo, o fator de crescimento semelhante à insulina (IGF2) (MOORE; HAIG, 1991). Contrário a isso, a mãe se protege suprimindo a expressão de genes, em seu alelo, que induzem o crescimento fetal (MOORE; HAIG, 1991).

Portanto, de uma correta tolerância materno-fetal depende o diálogo entre mãe e feto por fatores de sinalizações locais e sistêmicas mediadas pelas células da interface materno-fetal e pela migração de células fetais para o compartimento materno.

\subsection{DETECÇÃO DE TSPY NO SANGUE MATERNO}

O microquimerismo fetal é definido pela presença de material fetal no sangue periférico da mãe durante a gestação, sendo ele, célula fetal circulante ou DNA fetal circulante livre de célula (cffDNA, do inglês "cell-free fetal DNA"). A ocorrência desse tipo microquimerismo já foi amplamente descrito em humanos (BIANCHI; LO, 2001); camundongos (VERNOCHET; CAUCHETEUX; KANELLOPOULOS-LANGEVIN, 2007) e mais recentemente em bovinos (XI et al., 2006).

A ocorrência de microquimerismo fetal em animais com placenta epiteliocorial é ainda pouco compreendida. No entanto, em bovinos a presença do gene SRY já foi detectada tanto na fração celular do sangue materno a partir de 150 dias de gestação até 30 meses após o parto (TURIN et al., 2007b; TURIN et al., 2007a), como no soro materno na forma de cffDNA entre os dias 30 e 242 de gestação (XI JF et al., 2006; WANG et al., 2010). Nenhum destes trabalhos concentrou-se em 
demonstrar o microquimerismo fetal durante um dos períodos críticos para a manutenção da gestação, ou seja, após o reconhecimento materno-fetal até a transição da nutrição vitelínica para a placentária (D30 a D50) (ASSIS NETO et al., 2009).

Com o intuito de testar a ocorrência do microquimerismo fetal, nosso primeiro experimento foi focado na análise da presença de DNA de origem fetal utilizando como marcador o gene TSPY, na fração celular do sangue de vacas receptoras de embriões produzidos por fertilização in vitro (FIV) no dia 62 da gestação.

Tabela 1 - Número de embriões sexados por ultrassonografia transrretal (US) e positivos (pos) ou negativos (neg) por expressão de TSPY no sangue periférico da receptora.

\begin{tabular}{|c|c|c|c|c|}
\hline \multirow{3}{*}{ Tipo de Embrião } & \multirow{3}{*}{$\mathbf{N}$} & \multicolumn{3}{|c|}{ Tipo de Sexagem } \\
\hline & & \multirow{2}{*}{ US } & \multicolumn{2}{|c|}{ Expressão TSPY } \\
\hline & & & Pos & Neg \\
\hline Perdas Gestacionais & 5 & - & $2(40 \%)$ & $3(60 \%)$ \\
\hline Fêmea & 4 & 4 & $2(50 \%)$ & $2(50 \%)$ \\
\hline Macho & 25 & 25 & $15(60 \%)$ & $10(40 \%)$ \\
\hline
\end{tabular}

$\mathrm{N}$ - número de animais no grupo; US - animais sexados por ultrassonografia transretal; Pos positivo para TSPY; Neg - negativo para TSPY.

$\mathrm{Na}$ análise das amostras provenientes de receptoras gestando embriões machos, a presença do TSPY foi encontrada em 60\% (15 de 25) dos animais analisados. Ainda, em nosso laboratório em uma análise da presença do TSPY no sangue de 5 receptoras gestando animais clonados em idade gestacional entre 30 e 90 dias demonstrou a presença de TSPY a partir do dia 60 da gestação (dados não mostrados). Turin et al (2007b; 2007a) também tiveram falsos resultados negativos, porém a menor idade gestacional analisada foi aos 150 dias e usando o gene Y-S4. Uma explicação para os falsos negativos seria de que o teste não seria sensível o suficiente para a detecção da ocorrência do microquimerismo em todas as gestações de machos ou a diferença de intensidade de microquimerismo em cada gestação.

Duas das quatro (50\%) gestações de embriões fêmeas e duas das cinco (40\%) das perdas gestações apresentaram falsos positivos. Amostras de gestações 
de fêmeas também foram positivas em todas as fases de gestação quando usado o gene SRY (WANG et al., 2010). Portanto, esse fato sugere a permanência de microquimerismo fetal de gestação anterior ou da própria gestação mesmo depois da perda, corroborando com os achados de Turin et al (2007b; 2007a) onde foi detectado Y-S4 30 meses após o parto.

Nossos resultados juntamente com os resultados da literatura citada sugerem que há ocorrência de microquimerismo fetal em bovinos, e que estudos sobre os melhores marcadores desse fenômeno em bovinos, bem como a validação ou desenvolvimento de testes mais sensíveis seriam importantes.

\subsection{MAPEAMENTO DA INTERAÇÃO MATERNO-FETAL PELA GFP}

Com o intuito de estudar os mecanismo de microquimerismo fetal, foi desenvolvido um modelo bovino transgênico para a proteína verde fluorescente (GFP) para mapear a interação materno-fetal (BRESSAN et al., 2011). Para tanto, o a expressão de mRNA e da proteína GFP foram examinadas no cório, placentônio e no endométrio intercaruncular, por meio das técnicas de PCR em tempo real, Western blotting e imunohistoquímica.

\subsubsection{Expressão de GFP nos tecidos materno e fetais}

Amostras das gestações de conceptos transgênicos e clonados foram analisadas segundo sua expressão de GFP. $O$ cório teve a maior expressão relativa de GFP por ser composto apenas por tecido fetal. O placentônio apresentou uma expressão intermediária, provavelmente por ser uma região onde há tanto tecido. materno como fetal. Na região intercaruncular do endométrio, onde o contato materno fetal ocorre apenas pela aposição do epitélio coriônico com o epitélio uterino, houve menor expressão relativa (Figura 3) 


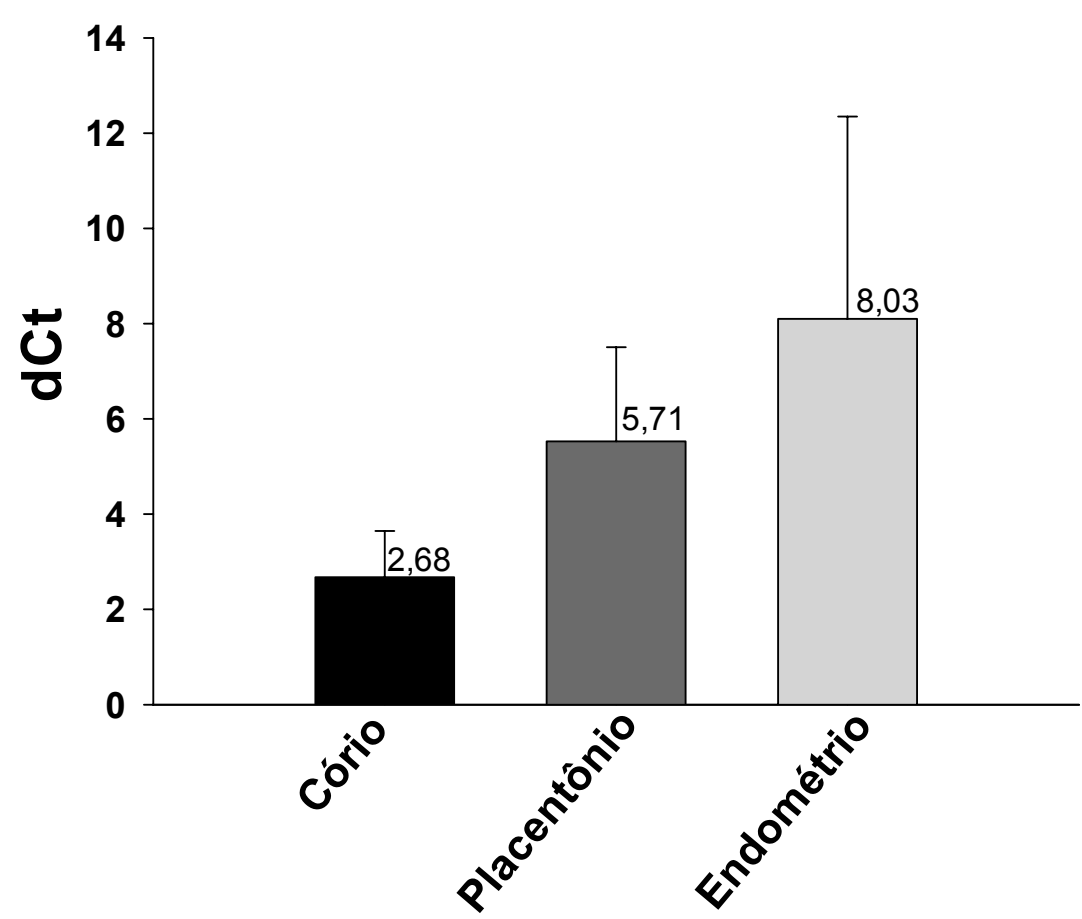

Figura 3 - Expressão relativa do mRNA do gene GFP no cório, placentônio e endométrio dos úteros gestantes utilizando a diferença entre os $\mathrm{Cts}(\mathrm{dCt})$ do gene GFP e o endógeno GAPDH.

Utilizando o cório como calibrador, foi encontrando no endométrio um $2^{\text {-ddCt }} \mathrm{de}$ 5,42 podendo-se estimar uma participação de 2,33\% de tecido fetal expressando GFP nesse tipo de amostra.

Para confirmar a expressão, mesmo que pequena, de mRNA do gene exógeno GFP na região intercaruncular do endométrio, buscamos a presença da proteína transcrita pelo gene exógeno GFP por meio da análise de Western Blotting. Como demonstrado na Figura 4, há formação de uma banda específica para GFP em todas as amostras de placentônio e da região intercaruncular do endométrio. A pequena concentração da proteína é demonstrada pela fina banda na região de 32 kDa que corresponde ao peso molecular da proteína verde fluorescente. Além disso, a análise de imunohistoquímica na região intercaruncular não demonstrou marcação positiva corroborando com o indicativo de baixa freqüência de células de origem fetal. Está em curso a investigação da presença de DNA do gene exógeno GFP em amostras da região intercaruncular das fêmeas, gestando fetos transgênicos, o que poderá permitir identificar se a origem da GFP encontrada é do extravasamento de conteúdo das células fetais na porção materna, ou da efetiva migração de células fetais para o endométrio. 


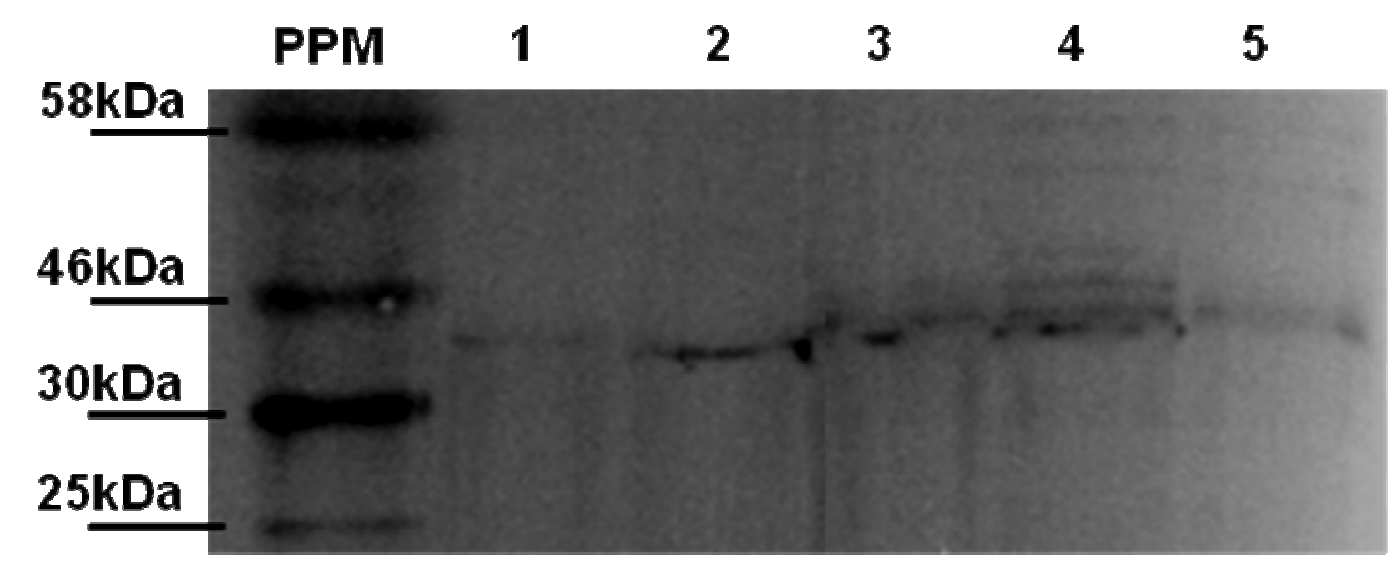

Figura 4 - Western blotting para GFP (32kDa) em tecidos placentários de gestações transgênicas e clonadas. PPM - padrão de peso molecular; 1- placentônio 30dias; 2- endométrio 90 dias; 3- endométrio D30; 4- endométrio D60; 5- placentônio D60.

A presença de GFP no endométrio pode ser explicada por um mecanismo descrito no sinciciotrofoblasto humano, mas desconhecido em bovinos, que será a ocorrência de exossomos carreando proteínas e pequenos fragmentos de RNA (MINCHEVA-NILSSON; BARANOV, 2010), realizando o transporte de tais moléculas para o epitélio materno.

Para o estudo da invasão das células trofoblásticas gigantes e o transporte de substâncias, reações imunohistoquímicas para GFP foram realizadas em amostras de placentônios, onde há uma maior interação entre mãe e feto.

Nossos resultados mostram que as células fetais apresentaram-se positivas para GFP, sendo que uma marcação mais tênue no mesênquima quando comparado ao epitélio coriônico (Figura 5). Neste as células trofoblásticas mononucleares pequenas apresentaram marcação bem evidente e uma reação muito intensa foi observada nas células trofoblásticas gigantes (CTG). Foi notado ainda com o avanço da gestação um aumento na expressão de GFP (Figuras 6a e $6 b)$.

Uma observação interessante foi da presença da GFP no epitélio materno (Figuras 5-8) sendo que, a maioria das células que compõem o epitélio materno demonstrou-se positivas para GFP enquanto o estroma endometrial não apresentou marcação. No epitélio materno vê-se a marcação para a GFP no citoplasma como também em torno da membrana plasmática indicando uma marcação no interstício celular (Figura 7). 
A presença de GFP no epitélio materno corrobora com os achados de marcação no endométrio mediante a técnica de Western Blotting; esta observação poderia ser compatível com a hipótese de transferência de substâncias para a mãe, por meio de exossomos, como já descrito em humanos (MINCHEVA-NILSSON; BARANOV, 2010).

Em regiões específicas, algumas CTGs aparentemente mononucleadas, quando em contato com o epitélio materno, apresentaram um volume de citoplasma maior do que as outras células trofoblásticas gigantes (Figura 7e). Isso indicaria que essas células estariam em processo degenerativo possivelmente pelo processo de morte celular programada.

Nas regiões de formação de sincício, as células trofoblásticas gigantes próximas ao epitélio materno apresentaram uma polarização citoplasmática tendo a sua marcação de GFP contralateral (Figura 6a). Com a aproximação das CTGs ao epitélio materno há um processo de remodelamento deste epitélio, tornando-o pavimentoso ao invés de colunar além de desestruturação próxima ao sincício (Figura 7 e 8a) de acordo com os modelos de formação sincicial propostos por Wooding (1992) e Leiser \& Kaufmann (1994). Além dessa modificação estrutural, a reação de imunohistoquímica para GFP pareceu ser menos intensa nessa região (Figura 8a), provavelmente em conseqüência da degranulação do conteúdo celular das CTGs anterior à fusão com o epitélio materno (WOODING, F.B., 1992). Formações sinciciais ocorrem, mas não sempre, próximos a vasos maternos (Figura 6d), o que poderia explicar a ocorrência de DNA fetal na fração celular do sangue periférico materno.

Essa migração das células trofoblásticas poderia ser um importante mecanismo de modulação do sistema materno frente aos antígenos fetais, uma vez que a exposição contínua de antígenos fetais para o sistema imune materno seria capaz de manter um estado tolerogênico local. Ainda, as CTB, em humanos e camundongos, expressam uma forma não clássica dos gene de MHC Ib (HLAG e PED). Com essas informações, levantamos a hipótese de que as CTBs expressam uma forma não clássica de MHC lb. Para testar essa hipótese, utilizamos um anticorpo que reconhece proteínas Qa2 (antígeno linfocitário Qa de região 2) de camundongos, que são pertencentes ao $\mathrm{MHC}$ classe $\mathrm{lb}$, em reações de imunohistoquímica. 
O mesmo padrão de formação sincicial encontrado para o GFP também pôde ser observado para a marcação com o anticorpo anti-Qa2, mostrando uma diminuição da expressão da proteína Qa2 nas células trofoblásticas gigantes em contato direto ao epitélio materno (Figura 8b). Com exceção dessas, as outras células trofoblásticas gigantes e todo $\circ$ trofoblasto apresentaram marcação fortemente positiva para Qa2 (Figura 9).

As células trofoblásticas gigantes, em camundongos, expressam MHC classe Ib para inibir a ativação células uNK evitando a lise das células fetais devido a sua baixa expressão de moléculas clássicas de MHC (BULMER; BILLINGTON; JOHNSON, 1984; HEEMSKERK et al., 2005). O fato das células trofoblásticas gigantes bovinas terem mostrado a diminuição de expressão durante a formação sincicial pode indicar um mecanismo de sinalização para a morte celular que resultaria no transporte de substâncias, e essa sinalização induziria e manteria a tolerância materna.

Também foi observada neste estudo, uma marcação positiva para Qa2 no epitélio materno dos placentônios, porém esta mesmo marcação é negativa no trofoblasto do cório (Figura 9). Hill et al (2000) também encontrou marcação positiva no epitélio materno e negativa no cório em gestação de clones utilizando anticorpo anti-MHC classe I bovino (II A19).

Em contraste, nas gestações de conceptos naturais, a expressão de MHC de classe I só ocorre na segunda metade da gestação (LOW et al., 1990; DAVIES; FISHER; SCHLAFER, 2000) tendo uma expressão aumentada no eptélio materno e no trofoblasto da região interplacentomal e no trofoblasto da região placentomal (DAVIES; FISHER; SCHLAFER, 2000). 


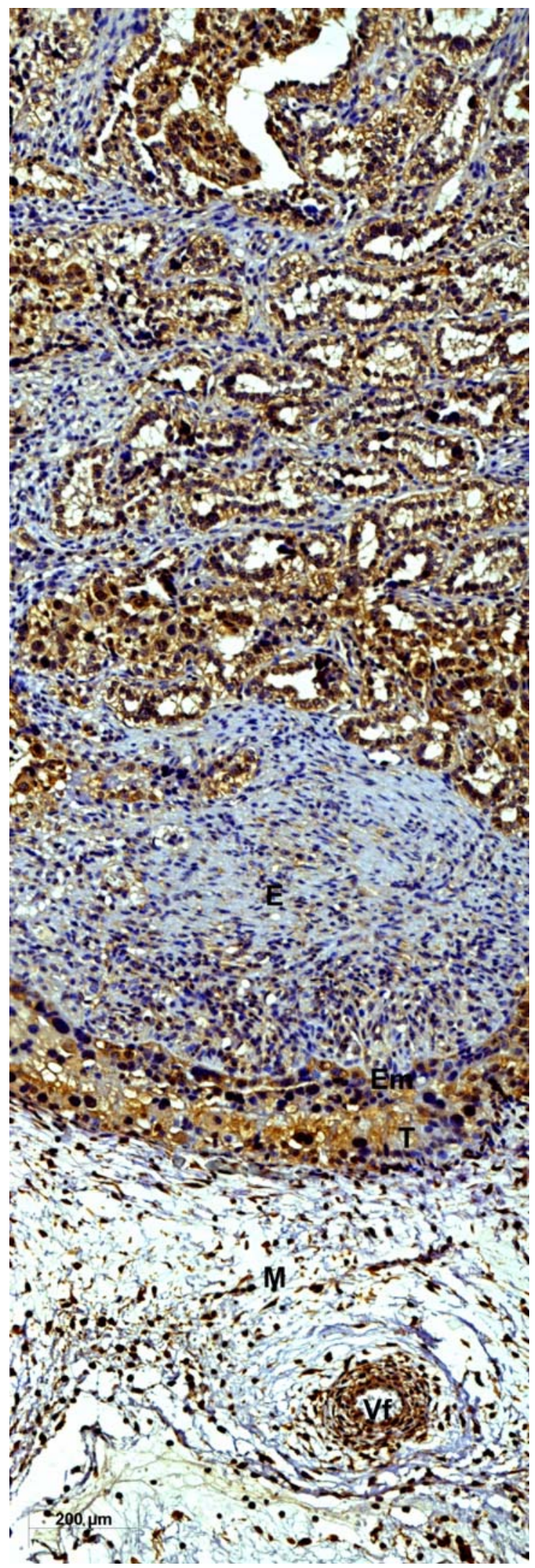

Figura 5 - Imunohistoquímica para proteína verde fluorescente (GFP) em placentônio de gestação de concepto bovino transgênico e clonado aos 90 dias. Observar a intensa marcação no trofoblasto $(T)$, e epitélio materno $(E m)$, mais tênue no mesênquina $(M)$ e negatica no estroma endometrial $(E)$. Barra $=200 \mu \mathrm{m}$. 

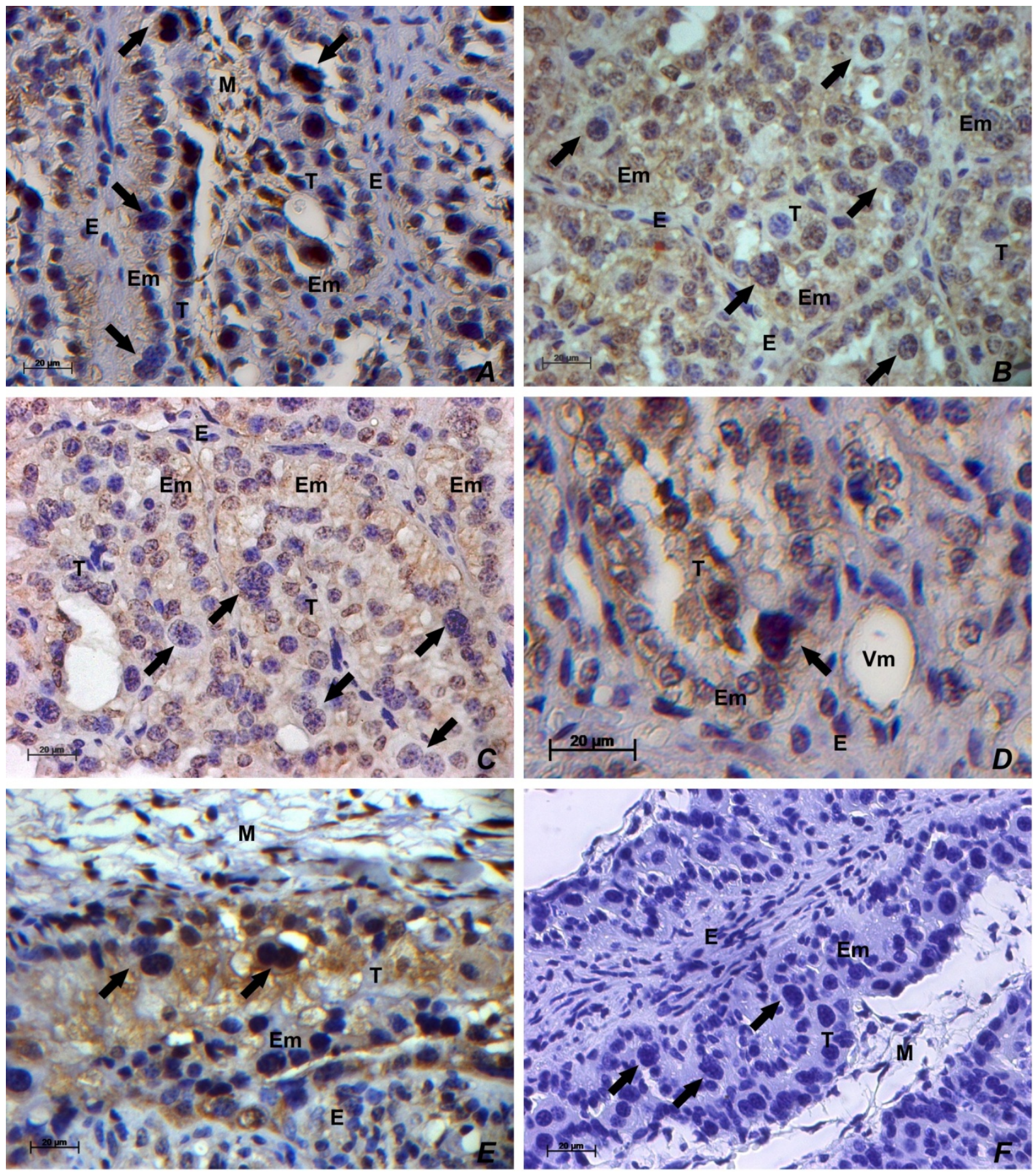

Figura 6 - Imunohistoquímica para proteína verde fluorescente (GFP) em placentônio de gestação de concepto bovino transgênico e clonado. As setas indicam as células trofoblásticas gigantes fundidas ou em processo de fusão com as células do epitélio materno (Em). Alguns sincícios são formados próximos a vasos maternos (Mv), como em d, porém sempre ocorre remodelamento do epitélio materno. A marcação é positiva para GFP nos tecidos fetais, sendo mais forte no trofoblasto $(T)$ e mais tênue no mesênquima ( $M)$, mas também pode ser observada no epitélio materno e marcação negativa no estroma endometrial (E). Observar marcação positiva mais fraca na gestação de 60 dias (a). Em a e f, 60 dias de gestação. Em b-e, 90 dias de gestação. Em f, controle negativo. Barra = $20 \mu \mathrm{m}$. 

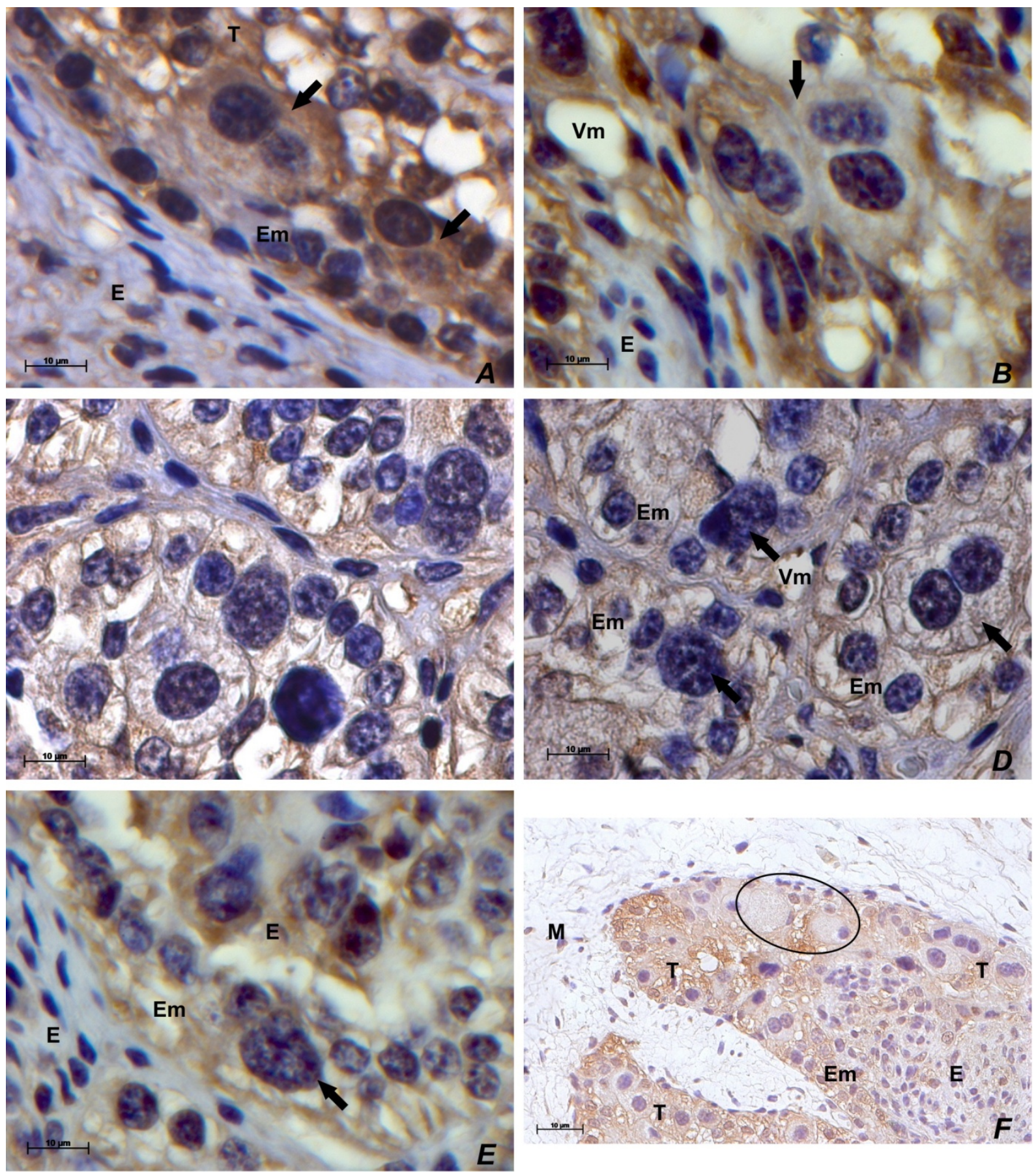

Figura 7 - Imunohistoquímica para proteína verde fluorescente (GFP) em placentônio de gestação de concepto bovino transgênico e clonado com 90 dias. As células trofoblásticas gigantes (setas) se aproximam e forçam um remodelamento do epitélio materno (Em), tornando-o pavimentoso ao invés de colunar (a-c). Observar em a-d a marcação tanto citoplasmática como no interstício do epitélio materno. Também em f, presença de células trofoblásticas gigantes (círculo) aparentemente mononucleares, apresentando o volume citoplasmático maior e o nuclear menor que as outras células trofoblásticas gigantes. Em a-d,e imunohistoquímica para proteína verde fluorescente. Trofoblasto (T), estroma endometrial $(E)$, mesênquima $(M)$ e vaso materno $(V m)$. Barra $=10 \mu m$. 

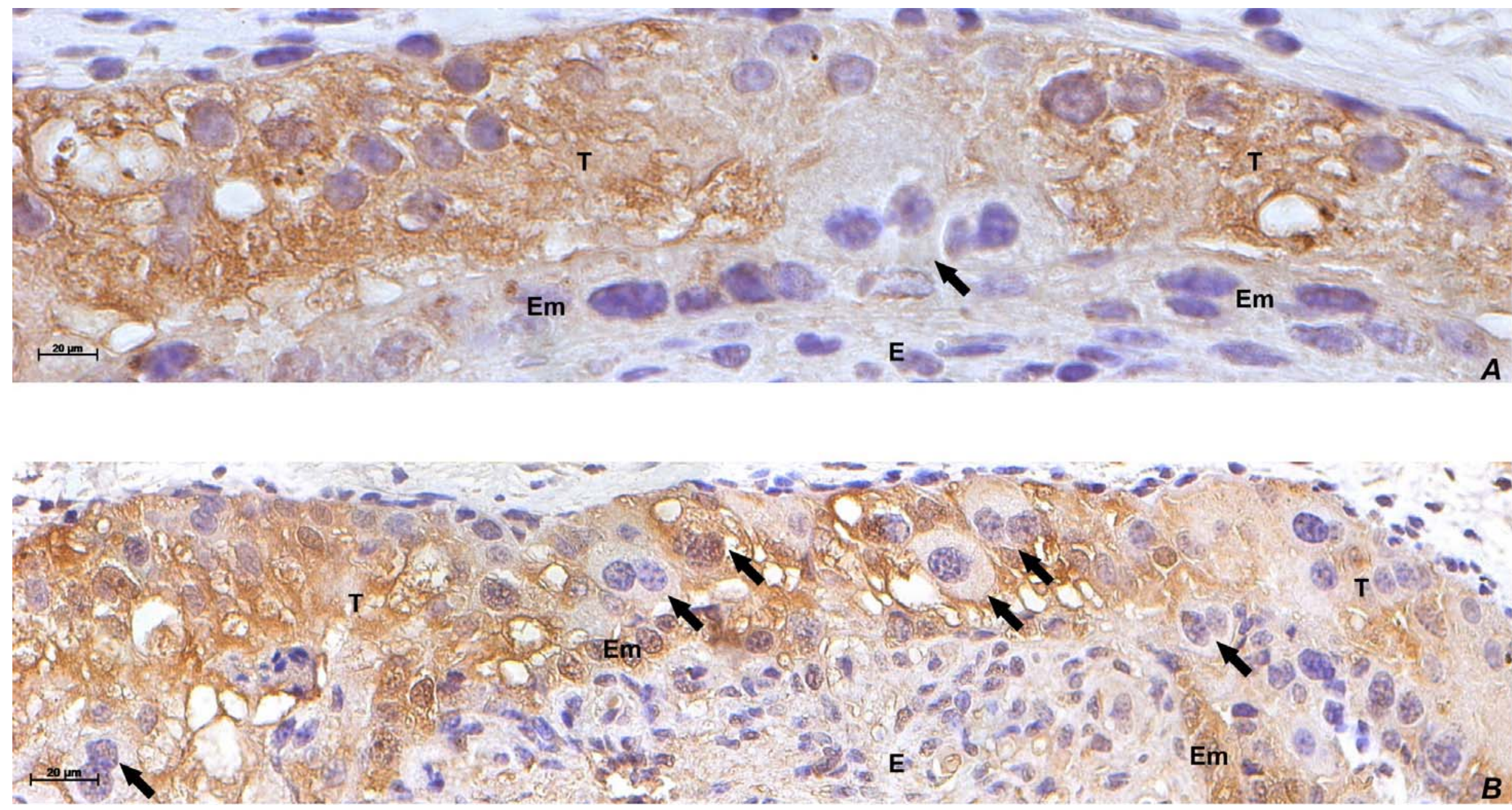

Figura 8 - Fotomicrografia da reação de imunohistoquímica para GFP (a) e Qa2 (b) em placentônio de gestação de concepto bovino transgênico e clonado aos 90 dias. Observar o epitélio materno $(E \mathrm{~m})$, porém ao centro ocorre a degradação do epitélio materno $(E m)$ e várias células trofoblásticas gigantes em profundidades diferentes de invasão no trofoblasto $(T)$. As células trofoblásticas gigantes em contato direto com o epitélio materno apresentam marcação negativa tanto para GFP como para Qa2. Barra $=20 \mu \mathrm{m}$. 

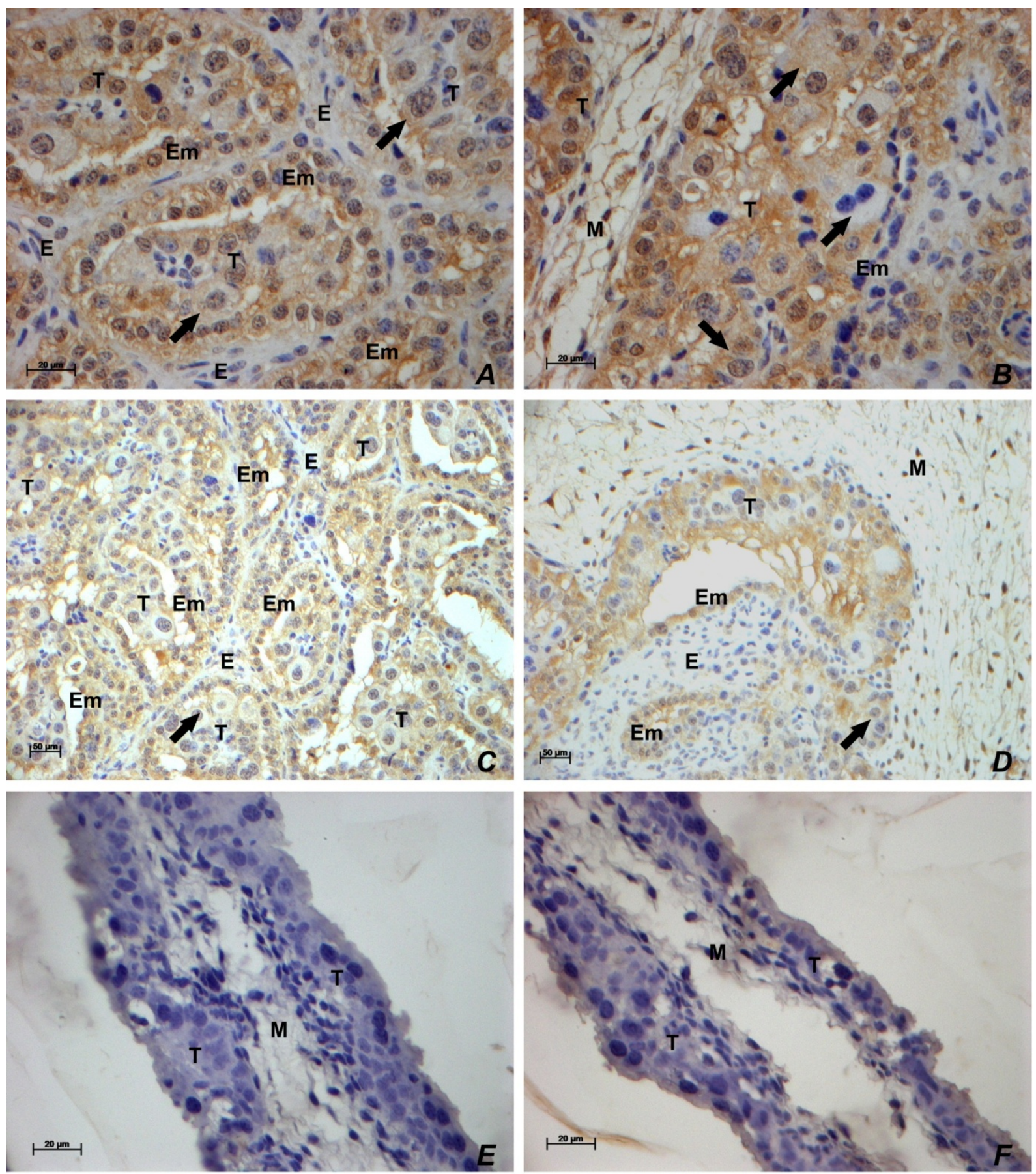

Figura 9 - Fotomicrografia da reação de imunohistoquímica para Qa2 em placentônio (a-d) e em cório (e,f) de gestação de concepto bovino transgênico e clonado. As setas indicam as células trofoblásticas gigantes fundidas ou em processo de fusão, notar a ausência de marcação para Qa2 nessas células (a-d). Observar marcação positiva para o epitélio materno $(E m)$

e o trofoblasto $(T)$ nos placentônios e negativa no trofoblasto e mesênqüima do cório. Em a-c, 90 dias de gestação; em d-f, 60 dias de gestação. Em e, controle negativo. Barra $=20 \mu \mathrm{m}$. 
CONCLUSÕES 


\section{CONCLUSÕES}

O gene TSPY pôde ser identificado no sangue periférico materno aos 62 dias, em gestação oriunda de fertilização in vitro, implicando em possível microquimerismo fetal logo após a transição da nutrição vitelínica para a placentária.

Tanto o cDNA como a proteína GFP foram encontrados em tecidos maternos, implicando em uma comunicação materno-fetal mais íntima em regiões de poucas trocas como a interplacentomal. Dois mecanismos de transporte da GFP e, por conseguinte, de outras substâncias podem ser hipotetizados: a degranulação das células trofoblásticas gigantes durante a formação sincicial e/ou o transporte para o epitélio materno por meio de liberação de exossomos pelas células trofoblásticas.

A expressão de MHC de classe $1 \mathrm{~b}$, avaliada mediante 0 anticorpo que reconhece o antígeno Qa2 murino, pôde ser identificada no trofoblasto, demonstrando um padrão de diminuição de expressão durante a formação sincicial, indicando um mecanismo de ativação das células UNK, favorecendo sua lise.

Em conjunto, este estudo mostra que na placenta bovina ocorre uma migração de células fetais além do epitélio materno e abre novas perspectivas para estudos de algumas características da interação materno-fetal ainda pouco explorada nos bovinos. 
MODELO HIPOTÉTICO 


\section{MODELO HIPOTÉTICO}
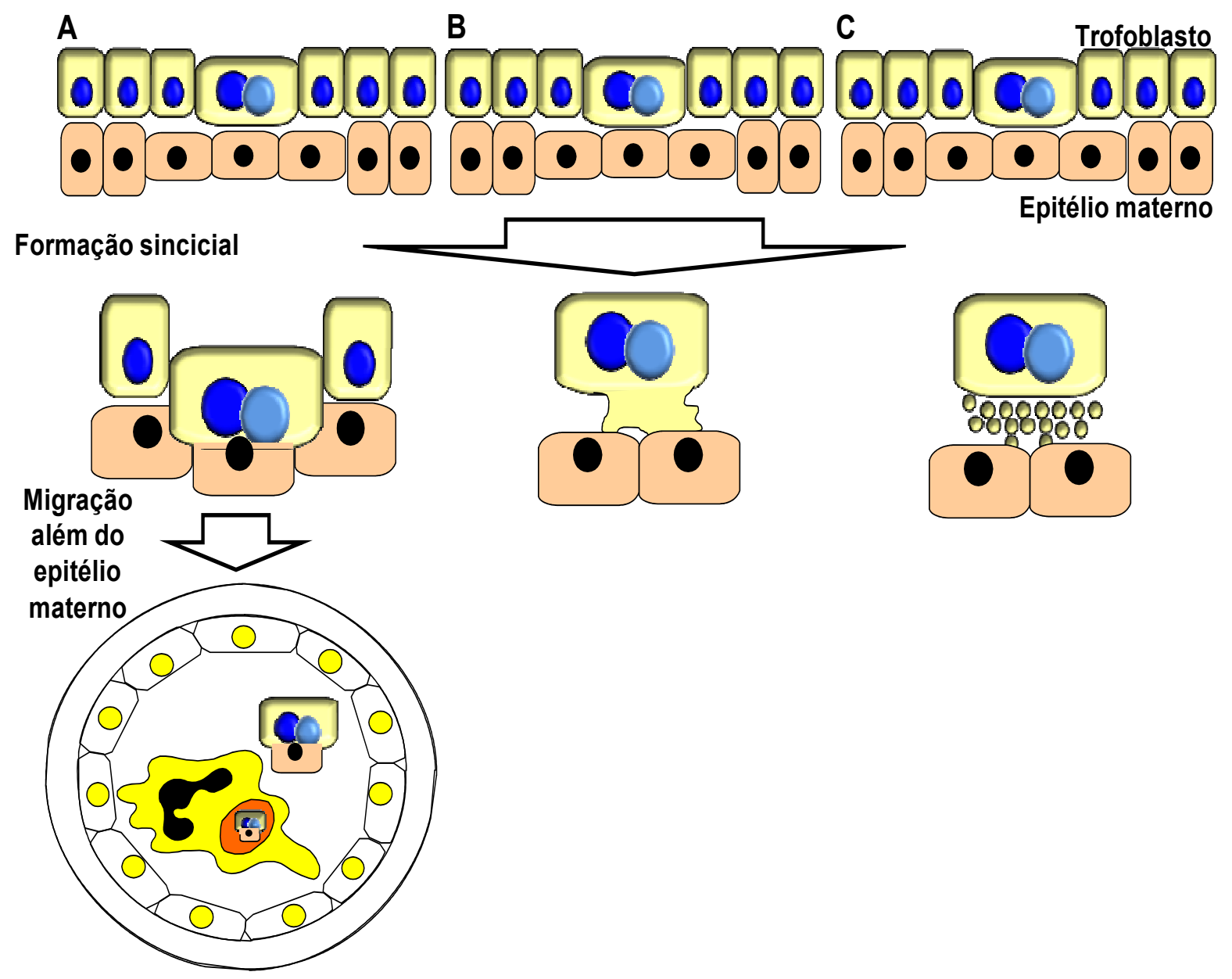

Figura 10 - Modelo hipotético da ocorrência de microquimerismo na placentação bovina. Em a, após fusão a célula trofoblástica gigante com o epitélio materno, ou a célula híbrida entra no vaso sanguíneo materno ou é fagocitada por um macrófago (localizado próximo ao epitélio materno) que entra em recirculação. $\mathrm{Em} b$, a célula trofoblástica gigante degranula seu conteúdo celular antes da fusão celular. Em c, a célula trofoblástica gigante transporta parte de seu conteúdo citoplasmática por meio de exossomos. 


\section{REFERÊNCIAS}

ALBERTS, B.; JOHNSON, A.; LEWIS, J.; RAFF, M.; ROBERTS, K.; WALTER, P. Molecular Biology of the cell. New York: Taylor \& Francis, 2008

ARMANT, D. R. Blastocysts don't go it alone. Extrinsic signals fine-tune the intrinsic developmental program of trophoblast cells. Developmental Biology, v. 280, n. 2, p. 260-280, 2005.

ASSIS NETO, A. C.; PEREIRA, F. T. V.; SANTOS, T. C.; AMBRÓSIO, C. E.; LEISER, R.; MIGLINO, M. A. Morpho-physical Recording of Bovine Conceptus (Bos indicus) and Placenta from Days 20 to 70 of Pregnancy. Reproduction in Domestics Animals, v. 45, n. 5, p. 760-772, 2009.

BARRETO, R. S. N.; BRESSAN, F. F.; OLIVEIRA, L. J.; PEREIRA, F. T. V.; PERECIN, F.; AMBRÓSIO, C. E.; MEIRELLES, F. V.; MIGLINO, M. A. Gene expression in placentation of farm animals: An overview of gene function during development. Theriogenology, v., n., p., 2011.

BIANCHI, D. W.; ZICKWOLF, G. K.; WEIL, G. J.; SYLVESTER, S.; DEMARIA, M. A. Male fetal progenitor cells persist in maternal blood for as long as 27 years postpartum. Proceedings of National Academy of Sciences, v. 93, n. 2, p. 705708, 1996.

BIANCHI, D. W.; WILLIAMS, J. M.; SULLIVAN, L. M.; HANSON, F. W.; KLINGER, K. W.; SHUBER, A. P. PCR quantitation of fetal cells in maternal blood in normal and aneuploid pregnancies. American Journal of Human Genetics, v. 61, n. 4, p. 822829, 1997.

BIANCHI, D. W.; LO, Y. M. Fetomaternal cellular and plasma DNA trafficking: the Yin and the Yang. Annals of the New York Academy of Sciences, v. 945, n., p. 119131, 2001.

BOTEZATU, I.; SERDYUK, O.; POTAPOVA, G.; SHELEPOV, V.; ALECHINA, R.; MOLYAKA, Y.; ANANEV, V.; BAZIN, I.; GARIN, A.; NARIMANOV, M.; KNYSH, V.; MELKONYAN, H.; UMANSKY, S.; LICHTENSTEIN, A. Genetic analysis of DNA excreted in urine: a new approach for detecting specific genomic DNA sequences from cells dying in an organism. Clinical Chemistry, v. 46, n. 8 Pt 1, p. 1078-1084, 2000.

BRESSAN, F. F.; DOS SANTOS MIRANDA, M.; PERECIN, F.; DE BEM, T. H.; PEREIRA, F. T.; RUSSO-CARBOLANTE, E. M.; ALVES, D.; STRAUSS, B.; BAJGELMAN, M.; KRIEGER, J. E.; BINELLI, M.; MEIRELLES, F. V. Improved production of genetically modified fetuses with homogeneous transgene expression after transgene integration site analysis and recloning in cattle. Cellular Reprograming, v. 13, n. 1, p. 29-36, 2011.

BRIDGER, P. S.; HAUPT, S.; LEISER, R.; JOHNSON, G. A.; BURGHARDT, R. C.; TINNEBERG, H. R.; PFARRER, C. Integrin activation in bovine placentomes and in 
caruncular epithelial cells isolated from pregnant cows. Biol Reprod, v. 79, n. 2, p. 274-282, 2008.

BULMER, J. N.; BILLINGTON, W. D.; JOHNSON, P. M. Immunohistologic identification of trophoblast populations in early human pregnancy with the use of monoclonal antibodies. American Journal of Obstetrics \& Gynecology, v. 148, n. 1, p. 19-26, 1984.

CARTER, A. M.; ENDERS, A. C. Comparative aspects of trophoblast development and placentation. Reproductive Biology and Endocrinology, v. 2, n., p. 46, 2004.

CARVALHO, A. F.; KLISCH, K.; MIGLINO, M. A.; PEREIRA, F. T.; BEVILACQUA, E. Binucleate trophoblast giant cells in the water buffalo (Bubalus bubalis) placenta. Journal of Morphology, v. 267, n. 1, p. 50-56, 2006.

CAZERTA, S. M. M.; MIGLINO, M. A.; MARQUES, R. S.; VULCANO, M.; PEREIRA, F. T. V. Caracterização das áreas hemófagas da placenta bovina [Characterization of hemophagous areas of the bovine placenta]. Pesquisa Veterinária Brasileira, v. 27, n. 6, p. 229-235, 2007.

CHUA, S.; WILKINS, T.; SARGENT, I.; REDMAN, C. Trophoblast deportation in preeclamptic pregnancy. Br J Obstet Gynaecol, v. 98, n. 10, p. 973-979, 1991.

COBB, S. P.; WATSON, E. D. Immunohistochemical study of immune cells in the bovine endometrium at different stages of the oestrous cycle. Research in Veterinary Science, v. 59, n. 3, p. 238-241, 1995.

CROY, B. A.; VAN DEN HEUVEL, M. J.; BORZYCHOWSKI, A. M.; TAYADE, C. Uterine natural killer cells: a specialized differentiation regulated by ovarian hormones. Immunological Reviews, v. 214, n. 1, p. 161-185, 2006.

DANTZER, V. Epitheliochorial Placentation. In: Knobil, E. e Neill, J. (Ed.). Encyclopedia of Reproduction: Academic Press, 1999. v.2, p.18-28.

DANTZER, V. Endometrium of epitheliochorial and endotheliochorial placentae. In: Glasser, S. R., Aplin, J. D., et al (Ed.). The Endometrium. London: Taylor \& Francis, 2002, p.352-364.

DAVIES, C. J.; FISHER, P. J.; SCHLAFER, D. H. Temporal and regional regulation of major histocompatibility complex class I expression at the bovine uterine/placental interface. Placenta, v. 21, n. 2-3, p. 194-202, 2000.

DAVIES, C. J.; HILL, J. R.; EDWARDS, J. L.; SCHRICK, F. N.; FISHER, P. J.; ELDRIDGE, J. A.; SCHLAFER, D. H. Major histocompatibility antigen expression on the bovine placenta: its relationship to abnormal pregnancies and retained placenta. Animal Reproduction Science, v. 82-83, n., p. 267-280, 2004.

DAVIES, C. J.; ELDRIDGE, J. A.; FISHER, P. J.; SCHLAFER, D. H. Evidence for expression of both classical and non-classical major histocompatibility complex class I genes in bovine trophoblast cells. American Journal of Reproductive Immunology, v. 55, n. 3, p. 188-200, 2006. 
DE SOUSA, P. A.; KING, T.; HARKNESS, L.; YOUNG, L. E.; WALKER, S. K.; WILMUT, I. Evaluation of gestational deficiencies in cloned sheep fetuses and placentae. Biology of Reproduction, v. 65, n. 1, p. 23-30, 2001.

DONALDSON, W. L.; ZHANG, C. H.; ORIOL, J. G.; ANTCZAK, D. F. Invasive equine trophoblast expresses conventional class I major histocompatibility complex antigens. Development, v. 110, n. 1, p. 63-71, 1990.

DUBERNARD, G.; ARACTINGI, S.; OSTER, M.; ROUZIER, R.; MATHIEU, M. C.; UZAN, S.; KHOSROTEHRANI, K. Breast cancer stroma frequently recruits fetal derived cells during pregnancy. Breast Cancer Research, v. 10, n. 1, p. R14, 2008.

EDWARDS, J. L.; SCHRICK, F. N.; MCCRACKEN, M. D.; VAN AMSTEL, S. R.; HOPKINS, F. M.; WELBORN, M. G.; DAVIES, C. J. Cloning adult farm animals: a review of the possibilities and problems associated with somatic cell nuclear transfer. Am J Reprod Immunol, v. 50, n. 2, p. 113-123, 2003.

FLORI, E.; DORAY, B.; GAUTIER, E.; KOHLER, M.; ERNAULT, P.; FLORI, J.; COSTA, J. M. Circulating cell-free fetal DNA in maternal serum appears to originate from cyto- and syncytio-trophoblastic cells. Case report. Human Reproduction, v. 19, n. 3, p. 723-724, 2004.

FOLDI, J.; KULCSAR, M.; PECSI, A.; HUYGHE, B.; DE SA, C.; LOHUIS, J. A.; COX, P.; HUSZENICZA, G. Bacterial complications of postpartum uterine involution in cattle. Animal Reproduction Science, v. 96, n. 3-4, p. 265-281, 2006.

GADI, V. K.; NELSON, J. L. Fetal microchimerism in women with breast cancer. Cancer Research, v. 67, n. 19, p. 9035-9038, 2007.

GOGOLIN-EWENS, K.; LEE, C.; MERCER, W.; BRANDON, M. Site-directed differences in the immune response to the fetus. Immunology, v. 66, n. 2, p. 312317, 1989.

HAMILTON, C. K.; FAVETTA, L. A.; DI MEO, G. P.; FLORIOT, S.; PERUCATTI, A.; PEIPPO, J.; KANTANEN, J.; EGGEN, A.; IANNUZZI, L.; KING, W. A. Copy number variation of testis-specific protein, Y-encoded (TSPY) in 14 different breeds of cattle (Bos taurus). Sexual Development, v. 3, n. 4, p. 205-213, 2009.

HANSEN, P. J.; STEPHENSON, D. C.; LOW, B. G.; NEWTON, G. R. Modification of immune function during pregnancy by products of the sheep uterus and conceptus. Journal of reproduction and fertility. Supplement, v. 37, n., p. 55-61, 1989.

HEEMSKERK, B.; LANKESTER, A. C.; VAN VREESWIJK, T.; BEERSMA, M. F.; CLAAS, E. C.; VELTROP-DUITS, L. A.; KROES, A. C.; VOSSEN, J. M.; SCHILHAM, M. W.; VAN TOL, M. J. Immune reconstitution and clearance of human adenovirus viremia in pediatric stem-cell recipients. Journal of Infectious Diseases, v. 191, n. 4, p. 520-530, 2005. 
HEYMAN, Y.; CHAVATTE-PALMER, P.; LEBOURHIS, D.; CAMOUS, S.; VIGNON, $X$.; RENARD, J. P. Frequency and occurrence of late-gestation losses from cattle cloned embryos. Biology of Reproduction, v. 66, n. 1, p. 6-13, 2002.

HIENDLEDER, S.; ZAKHARTCHENKO, V.; WENIGERKIND, H.; REICHENBACH, H.-D.; BRÜGGERHOFF, K.; PRELLE, K.; GOTTFRIED, B.; STOJKOVIC, M.; WOLF, E. Heteroplasmy in Bovine Fetuses Produced by Intra- and Inter-Subspecific Somatic Cell Nuclear Transfer: Neutral Segregation of Nuclear Donor Mitochondrial DNA in Various Tissues and Evidence for Recipient Cow Mitochondria in Fetal Blood. Biology of Reproduction, v. 68, n. 1, p. 154-166, 2003.

HILL, J. R.; BURGHARDT, R. C.; JONES, K.; LONG, C. R.; LOONEY, C. R.; SHIN, T.; SPENCER, T. E.; THOMPSON, J. A.; WINGER, Q. A.; WESTHUSIN, M. E. Evidence for placental abnormality as the major cause of mortality in first-trimester somatic cell cloned bovine fetuses. Biology of Reproduction, v. 63, n. 6, p. 17871794, 2000.

HUNT, J. S.; MANNING, L. S.; MITCHELL, D.; SELANDERS, J. R.; WOOD, G. W. Localization and characterization of macrophages in murine uterus. Journal of Leukocyte Biology, v. 38, n. 2, p. 255-265, 1985.

HUNT, J. S.; PETROFF, M. G.; BURNETT, T. G. Uterine leukocytes: key players in pregnancy. Seminars in Cell and Developmental Biology, v. 11, n. 2, p. 127-137, 2000.

HVIID, T. V. HLA-G in human reproduction: aspects of genetics, function and pregnancy complications. Human Reproduction Update, v. 12, n. 3, p. 209-232, 2006.

ISHITANI, A.; SAGESHIMA, N.; LEE, N.; DOROFEEVA, N.; HATAKE, K.; MARQUARDT, H.; GERAGHTY, D. E. Protein expression and peptide binding suggest unique and interacting functional roles for HLA-E, F, and $G$ in maternalplacental immune recognition. Journal of Immunology, v. 171, n. 3, p. 1376-1384, 2003.

JAKUBICZKA, S.; SCHNIEDERS, F.; SCHMIDTKE, J. A bovine homologue of the human TSPY gene. Genomics, v. 17, n. 3, p. 732-735, 1993.

JOUSAN, F. D.; OLIVEIRA, L. J.; HANSEN, P. J. Short-Term culture of in vitro produced bovine preimplantation embryos with insulin-like growth factor-i prevents heat shock-induced apoptosis through activation of the Phosphatidylinositol 3Kinase/Akt pathway. Mol Reprod Dev, v. 75, n. 4, p. 681-688, 2008.

KADOKAWA, H.; TAKUSARI, N.; MINEZAWA, M.; TAKAHASHI, H.; KARIYA, T. Absence od fetal cells in bovine jugular and uterine vein blood at a level of 1 in 10,000. Journal of Reproduction and Development, v. 42, n. 3, p. 205-208, 1996.

KNOX, K.; BAKER, J. C. Genomic evolution of the placenta using co-option and duplication and divergence. Genome Research, v. 18, n. 5, p. 695-705, 2008. 
KYDD, J. H.; BUTCHER, G. W.; ANTCZAK, D. F.; ALLEN, W. R. Expression of major histocompatibility complex (MHC) class 1 molecules on early trophoblast. Journal of reproduction and fertility. Supplement, v. 44, n., p. 463-477, 1991.

LANG, C. Y.; HALLACK, S.; LEISER, R.; PFARRER, C. Cytoskeletal filaments and associated proteins during restricted trophoblast invasion in bovine placentomes: light and transmission electron microscopy and RT-PCR. Cell Tissue Research, v. 315, n. 3, p. 339-348, 2004.

LEISER, R.; KAUFMANN, P. Placental structure: in a comparative aspect. Experimental and Clinical Endocrinology, v. 102, n. 3, p. 122-134, 1994.

LEISER, R.; KREBS, C.; KLISCH, K.; EBERT, B.; DANTZER, V.; SCHULER, G.; HOFFMANN, B. Fetal villosity and microvasculature of the bovine placentome in the second half of gestation. Journal of Anatomy, v. 191 ( Pt 4), n., p. 517-527, 1997.

LEMOS, D.; RIOS, A.; CAETANO, L.; LÔBO, R.; VILA, R.; MARTELLI, L.; TAKEUCHI, P.; RAMOS, E. Use of the TSPY gene for sexing cattle. Genetics and Molecular Biology, v. 28, n. 1, p. 117-119, 2005.

LI, C.; HOUSER, B. L.; NICOTRA, M. L.; STROMINGER, J. L. HLA-G homodimerinduced cytokine secretion through HLA-G receptors on human decidual macrophages and natural killer cells. Proceedings of National Academy of Sciences, v. 106, n. 14, p. 5767-5772, 2009.

LIVAK, K. J.; SCHMITTGEN, T. D. Analysis of relative gene expression data using real-time quantitative PCR and the 2(-Delta Delta C(T)) Method. Methods, v. 25, n. 4, p. 402-408, 2001.

LO, Y. M. Non-invasive prenatal diagnosis using fetal cells in maternal blood. Journal of Clinical Pathology, v. 47, n. 12, p. 1060-1065, 1994.

LO, Y. M.; NOAKES, L.; BOWELL, P. J.; FLEMING, K. A.; WAINSCOAT, J. S. Detection of fetal $\mathrm{RhD}$ sequence from peripheral blood of sensitized RhD-negative pregnant women. British Journal of Haematology, v. 87, n. 3, p. 658-660, 1994.

LO, Y. M.; CORBETTA, N.; CHAMBERLAIN, P. F.; RAI, V.; SARGENT, I. L.; REDMAN, C. W.; WAINSCOAT, J. S. Presence of fetal DNA in maternal plasma and serum. Lancet, v. 350, n. 9076, p. 485-487, 1997.

LO, Y. M.; TEIN, M. S.; LAU, T. K.; HAINES, C. J.; LEUNG, T. N.; POON, P. M.; WAINSCOAT, J. S.; JOHNSON, P. J.; CHANG, A. M.; HJELM, N. M. Quantitative analysis of fetal DNA in maternal plasma and serum: implications for noninvasive prenatal diagnosis. American Journal of Human Genetics, v. 62, n. 4, p. 768-775, 1998.

LOW, B. G.; HANSEN, P. J.; DROST, M.; GOGOLIN-EWENS, K. J. Expression of major histocompatibility complex antigens on the bovine placenta. Journal of reproduction and fertility, v. 90, n. 1, p. 235-243, 1990. 
MACINTYRE, D. M.; LIM, H. C.; RYAN, K.; KIMMINS, S.; SMALL, J. A.; MACLAREN, L. A. Implantation-associated changes in bovine uterine expression of integrins and extracellular matrix. Biology of Reproduction, v. 66, n. 5, p. 14301436, 2002.

MARQUES, R. D. S.; VULCANO, M.; CAZERTA, S. M. M.; MIGLINO, M. A.; ASSIS NETO, A. C.; PEREIRA, F. T. V. Caracterização morfológica da região intercaruncular uterina de vacas e búfalas gestantes [Morphological characterization of the intercaruncular region of pregnant cows and water buffalo cows]. Biotemas, v. 20, n. 3, p. 103-114, 2007.

MEIRELLES, F. V.; BIRGEL, E. H.; PERECIN, F.; BERTOLINI, M.; TRALDI, A. S.; PIMENTEL, J. R.; KOMNINOU, E. R.; SANGALLI, J. R.; NETO, P. F.; NUNES, M. T.; POGLIANI, F. C.; MEIRELLES, F. D.; KUBRUSLY, F. S.; VANNUCCHI, C. I.; SILVA, L. C. Delivery of cloned offspring: experience in Zebu cattle (Bos indicus). Reproduction Fertility and Development, v. 22, n. 1, p. 88-97, 2010.

MESS, A.; CARTER, A. M. Evolution of the placenta during the early radiation of placental mammals. Comparative Biochemistry and Physiology Part A: Molecular \& Integrative Physiology, v. 148, n. 4, p. 769-779, 2007.

MIGLINO, M. A.; DIDIO, L. J. Vasculature of bovine placentas studied by scanning electron microscopy of corrosion casts. Italian Journal of Anatomy and Embryology, v. 97, n. 1, p. 23-35, 1992.

MIGLINO, M. A.; PEREIRA, F. T. V.; VISINTIN, J. A.; GARCIA, J. M.; MEIRELLES, F. V.; RUMPF, R.; AMBRÓSIO, C. E.; PAPA, P.; SANTOS, T. C.; CARVALHO, A. F.; LEISER, R.; CARTER, A. M. Placentation in cloned cattle: structure and microvascular architecture. Theriogenology, v. 68, n. 4, p. 604-617, 2007.

MINCHEVA-NILSSON, L.; BARANOV, V. The role of placental exosomes in reproduction. American Journal of Reproductive Immunology, v. 63, n. 6, p. 520533, 2010.

MOFFETT-KING, A. Natural killer cells and pregnancy. Nature Reviews Immunology, v. 2, n. 9, p. 656-663, 2002.

MOFFETT, A.; LOKE, C. Immunology of placentation in eutherian mammals. Nature Reviews Immunology, v. 6, n. 8, p. 584-594, 2006.

MOORE, T.; HAIG, D. Genomic imprinting in mammalian development: a parental tug-of-war. Trends Genetics, v. 7, n. 2, p. 45-49, 1991.

MOSSMAN, H. W. Vertebrate Fetal Membranes. New Brunswisk: Rutgers University Press, 1987, v.1. 383 p.

NAKANO, H.; TAKAHASHI, T.; IMAI, K.; HASHIZUME, K. Expression of placental lactogen and cytokeratin in bovine placental binucleate cells in culture. Cell Tissue Research, v. 303, n. 2, p. 263-270, 2001. 
PEREIRA, F. T.; BRAGA, F. C.; BURIOLI, K. C.; KFOURY JR, J. R.; OLIVEIRA, L.; PAPA, P.; CARVALHO, A. F.; AMBROSIO, C. E.; BAZER, F. W.; MIGLINO, M. A. Transplacental Transfer of Iron in the Water Buffalo (Bubalus bubalis): Uteroferrin and Erythrophagocytosis. Reproduction in Domestics Animals, v. 45, n. 5, p. $907-$ 914, 2009.

PFARRER, C.; HIRSCH, R.; LEISER, R. Interaction of integrin receptors extracellular matrix is involved in trophoblast giant cell migration in bovine placentomas. Placenta, v. 24, n. 6, p. 588-597, 2003.

ROBERTS, E. M. F. D.; HIB, J. Bases da biologia celular e molecular. Rio de Janeiro: Guanabara Koogan, 1998

ROSBOTTOM, A.; GIBNEY, E. H.; GUY, C. S.; KIPAR, A.; SMITH, R. F.; KAISER, P.; TREES, A. J.; WILLIAMS, D. J. Upregulation of cytokines is detected in the placentas of cattle infected with Neospora caninum and is more marked early in gestation when fetal death is observed. Infection and Immunity, v. 76, n. 6, p. 23522361, 2008.

TEKIN, S.; HANSEN, P. J. Regulation of numbers of macrophages in the endometrium of the sheep by systemic effects of pregnancy, local presence of the conceptus, and progesterone. American Journal of Reproductive Immunology, v. 51, n. 1, p. 56-62, 2004.

THE BOVINE GENOME SEQUENCING AND ANALYSIS CONSORTIUM; ELSIK, C. G.; TELLMAN, R. L.; WORLEY, K. C. The genome sequence of taurine cattle: a window to ruminant biology and evolution. Science, v. 324, n. 5926, p. 522-528, 2009.

TILBURGS, T.; SCHERJON, S. A.; VAN DER MAST, B. J.; HAASNOOT, G. W.; VERSTEEG, V. D. V.-M. M.; ROELEN, D. L.; VAN ROOD, J. J.; CLAAS, F. H. Fetalmaternal HLA-C mismatch is associated with decidual $T$ cell activation and induction of functional $T$ regulatory cells. Journal of Reproductive Immunology, v. 82, n. 2, p. 148-157, 2009.

TURIN, L.; TRIBBIOLI, G.; INVERNIZZI, P.; GRATI, F. R.; CREMA, S.; LAIBLE, G.; RIVA, F. Fetal microchimerism in normal and embryo transfer bovine pregnancies. Veterinary Research Communications, v. 31 Suppl 1, n., p. 205-207, 2007a.

TURIN, L.; INVERNIZZI, P.; WOODCOCK, M.; GRATI, F. R.; RIVA, F.; TRIBBIOLI, G.; LAIBLE, G. Bovine fetal microchimerism in normal and embryo transfer pregnancies and its implications for biotechnology applications in cattle. Biotechnology Journal, v. 2, n. 4, p. 486-491, 2007b.

VANSELOW, J.; FURBASS, R.; TIEMANN, U. Cultured bovine trophoblast cells differentially express genes encoding key steroid synthesis enzymes. Placenta, v. 29 , n. 6 , p. 531-538, 2008.

VERKAAR, E. L.; ZIJLSTRA, C.; VAN 'T VELD, E. M.; BOUTAGA, K.; VAN BOXTEL, D. C.; LENSTRA, J. A. Organization and concerted evolution of the ampliconic Ychromosomal TSPY genes from cattle. Genomics, v. 84, n. 3, p. 468-474, 2004. 
VERNOCHET, C.; CAUCHETEUX, S. M.; KANELLOPOULOS-LANGEVIN, C. Bidirectional cell trafficking between mother and fetus in mouse placenta. Placenta, $v$. 28, n. 7, p. 639-649, 2007.

VOGEL, P. The current molecular phylogeny of Eutherian mammals challenges previous interpretations of placental evolution. Placenta, v. 26, n. 8-9, p. 591-596, 2005.

VOGEL, T.; DECHEND, F.; MANZ, E.; JUNG, C.; JAKUBICZKA, S.; FEHR, S.; SCHMIDTKE, J.; SCHNIEDERS, F. Organization and expression of bovine TSPY. Mammalian Genome, v. 8, n. 7, p. 491-496, 1997a.

VOGEL, T.; BORGMANN, S.; DECHEND, F.; HECHT, W.; SCHMIDTKE, J. Conserved Y-chromosomal location of TSPY in Bovidae. Chromosome Res, v. 5, n. 3, p. 182-185, 1997b.

VOGEL, T.; SCHMIDTKE, J. Structure and function of TSPY, the Y-chromosome gene coding for the "testis-specific protein". Cytogenetics and Cell Genetics, v. 80, n. 1-4, p. 209-213, 1998.

WALKNOWSKA, J.; CONTE, F. A.; GRUMBACH, M. M. Practical and theoretical implications of fetal-maternal lymphocyte transfer. Lancet, v. 1, n. 7606, p. 11191122, 1969.

WANG, G.; CUI, Q.; CHENG, K.; ZHANG, X.; XING, G.; WU, S. Prediction of fetal sex by amplification of fetal DNA present in cow plasma. Journal of Reproduction and Development, v. 56, n. 6, p. 639-642, 2010.

WELLS, D. N. Animal cloning: problems and prospects. Rev Sci Tech, v. 24, n. 1, p. 251-264, 2005.

WOODING, F. B.; BECKERS, J. F. Trinucleate cells and the ultrastructural localisation of bovine placental lactogen. Cell Tissue Res, v. 247, n. 3, p. 667-673, 1987.

WOODING, F. B. Current topic: the synepitheliochorial placenta of ruminants: binucleate cell fusions and hormone production. Placenta, v. 13, n. 2, p. 101-113, 1992.

WOODING, F. B.; MORGAN, G.; FORSYTH, I. A.; BUTCHER, G.; HUTCHINGS, A.; BILLINGSLEY, S. A.; GLUCKMAN, P. D. Light and electron microscopic studies of cellular localization of oPL with monoclonal and polyclonal antibodies. J Histochem Cytochem, v. 40, n. 7, p. 1001-1009, 1992.

WOODING, F. B. P.; FLINT. Placentation. In: (Ed.). Marshall's Physiology of Reproduction. London: Chapman and Hall, 1994. v.III, p.233-460.

WOODING, F. B. P.; MORGAN, G.; MONAGHAN, S.; HAMON, M.; HEAP, R. B. Functional specialization in the ruminant placenta: Evidence for two populations of 
fetal binucleate cells of different selective synthetic capacity Placenta, v. 17, n. 1, p. 75-86, 1996.

XI, J.; JIA, B.; LI, R.; CHEN, W.; WANG, D.; YANG, S. Rapid sex identification of embryos in different developmental stages by blood of pregnant dairy cattle. Journal of Shihezi University(Natural Science), v. 24, n. 4, p. 446-449, 2006.

XI JF; JIA B; LI RY; CHEN WF; WANG DS; SM., Y. Rapid sex identification of embryos in different developmental stages by blood of pregnant dairy cattle. $\mathbf{J}$ Shihezi Univ Natural Sci, v. 24, n. 4, p. 446-449, 2006.

YOUNG, L. E.; SINCLAIR, K. D.; WILMUT, I. Large offspring syndrome in cattle and sheep. Reviews of Reproduction, v. 3, n. 3, p. 155-163, 1998.

ZEILER, M.; LEISER, R.; JOHNSON, G. A.; TINNEBERG, H.-R.; PFARRER, C. Development of an in vitro model for bovine placentation: a comparison of the in vivo and in vitro expression of integrins and components of extracellular matrix in bovine placental cells. Cells Tissues Organs, v. 186, n. 4, p. 229-242, 2007.

ZOLI, A.; DEMEZ, P.; BECKERS, J.; REZNIK M; A, B. Light and electron microscopic immunolocalization of bovine pregnancy-associated glycoprotein in the bovine placentome. Biology of Reproduction, v. 46, n. 4, p. 623-639, 1992. 